SB 401

. $\mathrm{K} 4$ 


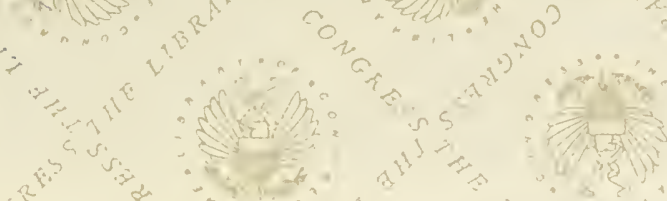

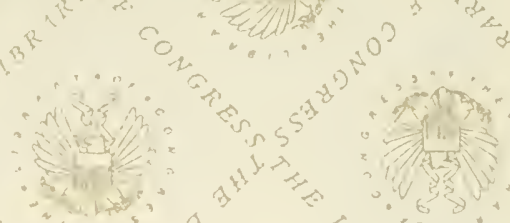

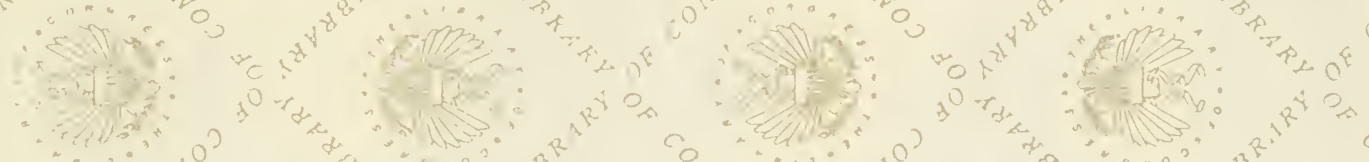

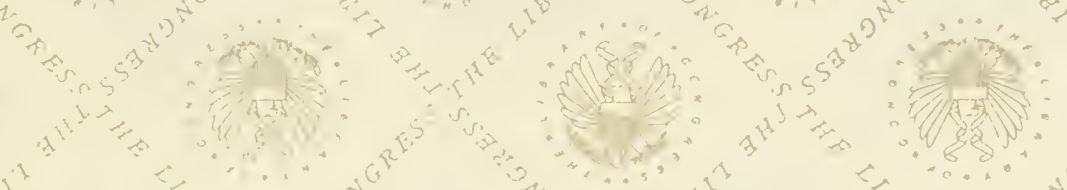

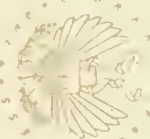

$\therefore$ :

and

\&.

0 



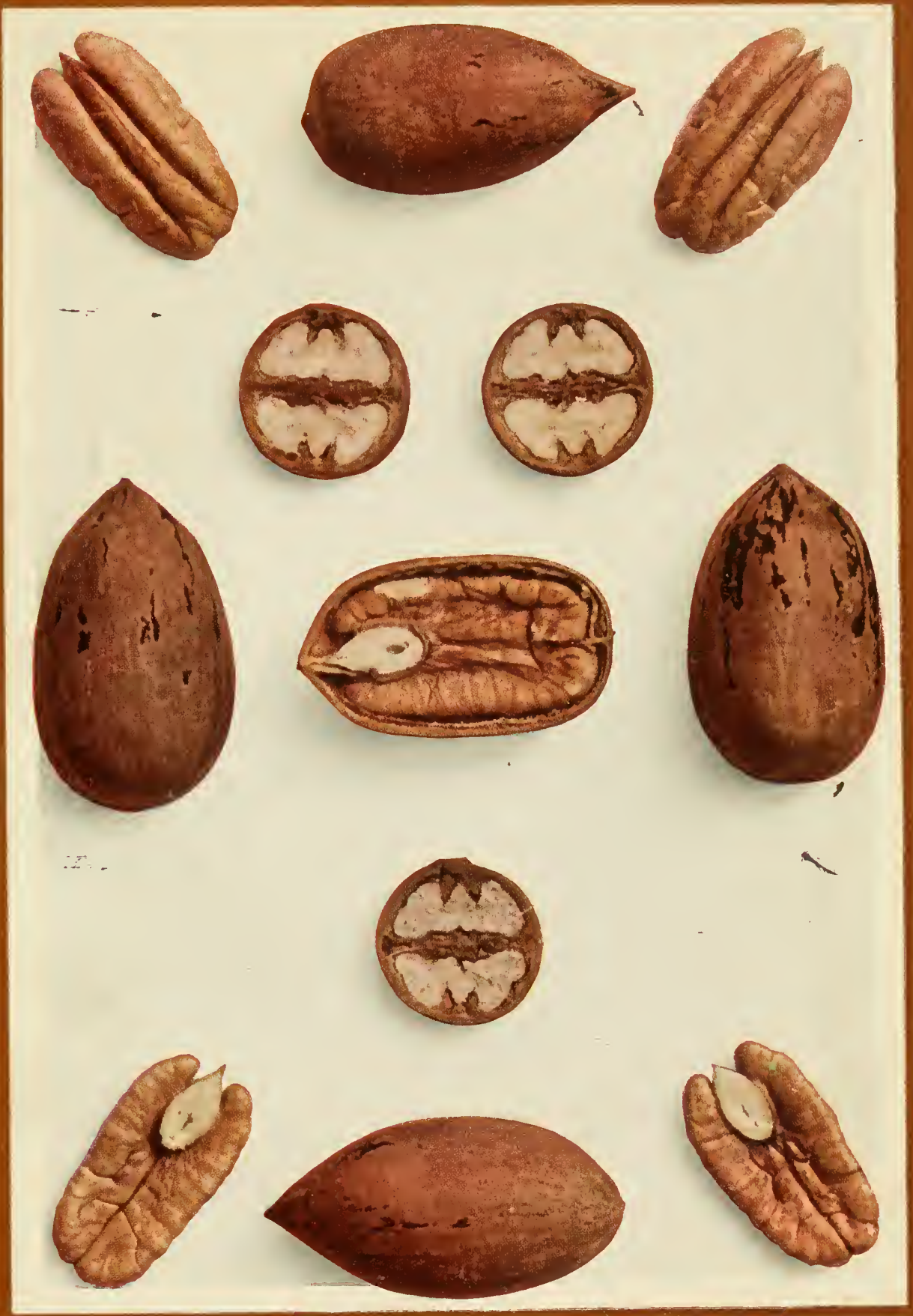

PaperShell Pecans 

Ke.jetro pecan invkany $12=-12$

\section{The Paper Shell Pecan}

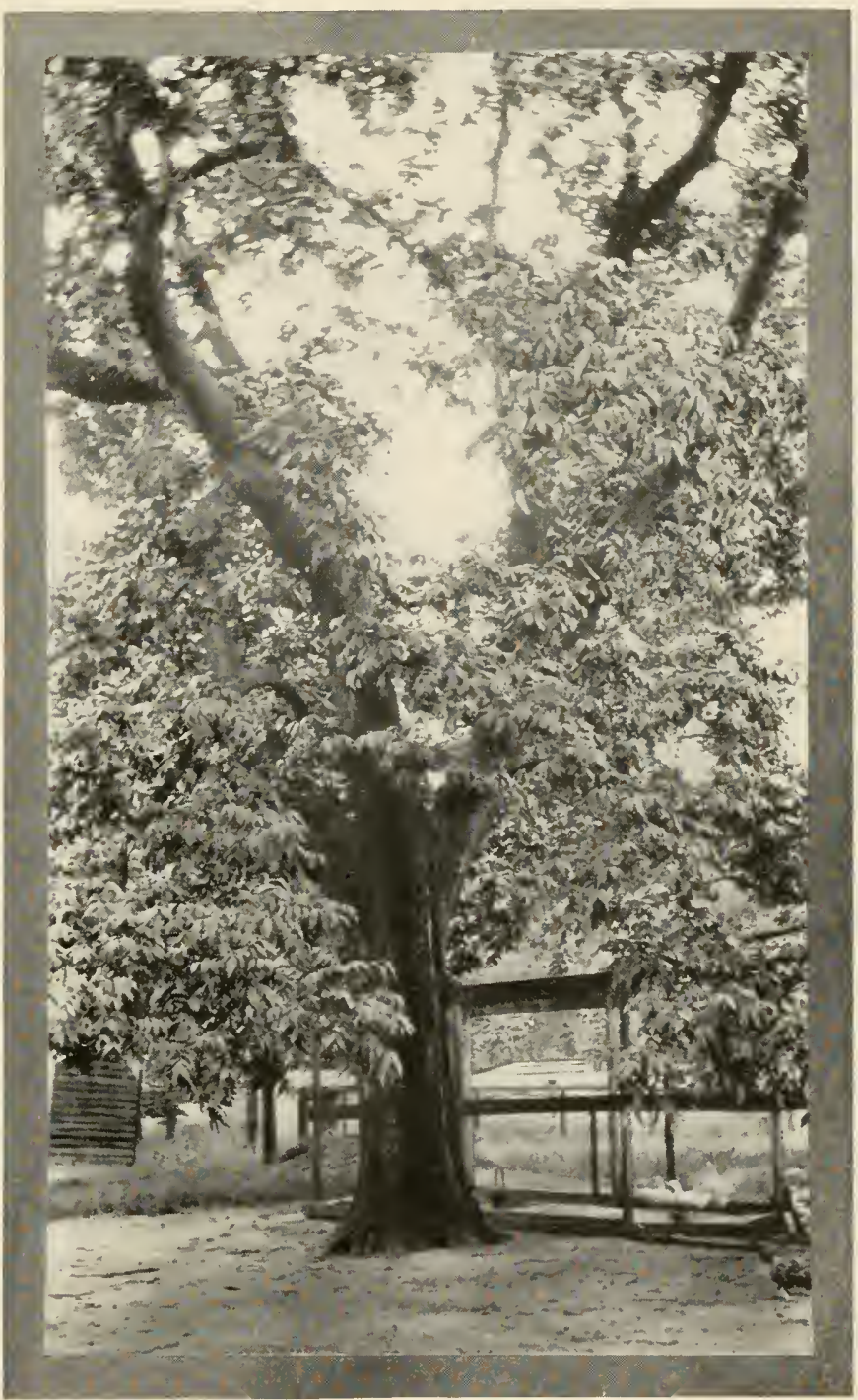

A Large Pecan Nut Tree at Albany, Georgia, which Yielded 800 lbs. in 1912

The Tree That Bears Dollars 
ELAM G. HESS

\section{(C) Cl.A411549}

PRESS OF

no

LANCASTER, PA. 


\section{Foreword}

About a hundred years ago the railroad offered an investment opportunity which the Vanderbilts were wise enough to see-and to seize. Iou know that the V'anderbilt wealth has lasted through generations-increasing year by year.

About fifty years ago there was a similar opportunity offered in steel-demander by the rapidly growing industries. The name of Carnegie heads the list of the famous "thousand steel millionaires"-made rich by foresight.

Forty years ago electricity offered its opportunities to Edison -and to many others who have become extremely wealthy because they combined courage with foresight.

Narvelous as have been the fortunes in railroads, in steel and in electricity, we are to-day, says the Luther Burbank Society in its book, "Give the Boy a Chance," "facing an opportunity four hundred tines bigger than the railroad opportunity was a hundred years ago, eight hundred times bigger than electricity offered at its inception, fifteen hundred times bigger than the steel opportunity which Mr. Carnegie found--because agriculture is just by these amounts bigger than those other industries."

From land-the most permanent basis of wealth-immense fortumes of today and tomorrow are being drawn. Anerica is beginning to see a new vision, its agriculture is taking a newer, more profitable form.

What is the biggest future in agriculture?

When James J. Hill staked his all in apples and received in return a profit of ten million dollars - he was merely a pioneer in the new type of farming.

\section{Not Enough Nuts for Demand-None for Export.}

"The present pecan orchards of improved varieties total many thousand trees, but there is no doubt that even when present plantings come into bearing, the growers will be as short of supplying the demand as they are now; nutuch less able to take care of the large export trade, which can undoubtedly be developed. However, it will be some time yet until we can take care of our own markets," Prof. H. Harold Hume, Glen St. Mary, Fia. 
In the Saturday Evening Post, Norember 29, I9I3, on page 56. we read: "Tree crops is the next big thing in farming:" says J. Russell Smith, "after an I8,00o mile journey through the nutgrowing countries."

The last portion of that conment is especially significant when considered in connection with the following statement of Luther Burbank, the Edison of Agriculture: "Paper Shell Pecans of the improved varieties are the most delicious, as well as the most nutritious nuts in the world. They are higher in food value than any other nuts, either native or foreign."

In The Country Gentleman, August I+. I9 5, we read: "The tree that yields a pound or two of nuts at five years of age is counted upon for twenty to fifty pounds by the tenth year, and after that the yield grows beyond anything known in fruit trees, because the Pecan at maturity is a forest giant."

In the face of such facts, is it not wise to consider carefully the interesting facts on Paper Shell Pecans found within?

\section{KEYSTONE PECAN PLANTATION \\ Calhoun County, Georgia.}

\section{ELAM G. HESS,}

Manheim, Lancaster County, $\mathrm{Pa}$.

President of Keystone Pecan Company Member of National Nut Growers' Association

From one of the largest nut-tree nurseryulen in the world: "The denand for Pecans of all descriptions is increasing faster than the supply. Ten years ago I bought wild Pecans in Waco, Texas, retail at $4^{1 / 2}$ cents. These same nuts are now worth 12 to 15 cents wholesale. The large Pecans that we raise bring from 50 cents per pound up to $\$ 1.25$. We do not think that the price will ever drop a great deal, though a great incone can be had even at 25 cents per pound or even lower if trees are ten or more years of age. If one had $\$_{1,000}$ to invest they wonld be satisfied with $7 \%$, which is $\$ 70$, yet five or six trees will bring in this income. There are no diseases or insects that are bad on the Pecan, nothing like as bad as with the Apple, Peach, etc., nothing that is anywhere near ruinous. Pecan trees are naturally a wild tree and therefore very hardy." 


\section{Right Foods-An Increasing Demand.}

No matter what may happen, the demand for nourishing foods is sure to grow so long as the population increases. Railroads, steel, electricity-all are recent developments, none of them indispensable to mankind. But existence itself depends on nourishing foods.

"Then," you say, "no business should be surer than that of supplying food to the growing population of America."

Correct, provided you supply the right food.

For food standards are changing. Prove that fact, if you will, by the figures of the U. S. Census Burean for the years Igoo and IgIO.

During that period the population of the United States increased from 75,091,575 to 91,972,266-an increase of virtually $223 /$ IO per cent. Therefore the production of any foodstuff should increase by the same percentage during that period to provide for the same consumption per capita.

Has the consumption of beef increased during that period? Apparently not - for there were 8.7 per cent. less cattle on the farms in IgIo than in Igoo. Nor was there any material increase in imports. The price of beef increased in that period-but not so greatly as other prices. For the value of all cattle on American farms increased only s.6 per cent. between Igoo and I9Io-an increase only one-fourth as great as the increase in population.

There was a loss of 7.4 per cent. in the number of swine on American farms and a decrease of I. 4.7 per cent. in the number of sheep-the inevitable result of which loss while population was increasing to the extent of $223 /$ Io per cent. was an increase per pound in pork, ham, bacon, mutton, etc., which automatically cut off a large part of the demand.

There was a loss of 7.4 per cent. in the number of swine on American farms and a decrease of I 4.7 per cent. in the number of sheep-the ineritable result of which loss automatically cut off a large part of the demand which was created by the population increased 22.3 per cent.

\section{"More Nuts-Less Animal Food-A Healthier Race."}

"I found the Hess High Grade Seedling Pecans delicious eating, and only wish I could have them constantly on my table.

As to the food value of the pecan. I an fully satisfied that it is a perfect subsitute for not only meat, but for butter and all animal fats. When we learn to eat more nuts and less animal foods there will be a healthier race in the land." IV. K. R., Sunnyrale, Cal. 


\section{Poultry Gains Fail to Equal Increase of Population.}

Poultry was the only exception among meats to this history of diminishing supply, increased prices and diminishing demand. Yet the gain in the number of all fowls on American farms was only 17 per cent. while the population was increasing 22 3/ IO per cent.; while the American production of nut foods was increasing 55.7 per cent. in the same period without beginning to meet the demand.

For the increase in value of the American nut crop was 128.1 per cent., while the increase in consumption required an increase in imports so great that in 1910 America was supplying only one-fourth of the nuts it was eating (that is, America produced in 1910 muts to the value of $\$ 4,447,674$, and imported nuts to a value of $\$ 13,246$, $742)$; while in 1900 America had supplied over one-half of the nuts it ate $(\$ 1.949 .93 \mathrm{I}$ is the value of nuts raised in America in I9Io, to $\$ 3,+84,65$ I value imported $)$.

Even the man, or the woman, who has learned by experience that nut meat is the healthiest form of real meat value, is astonished when he or she takes the authentic figures of the United States Census Agricultural reports and import statistics to learn how many of the thinking people among his fellow countrymen have proved their belief in the same facts. And the man who has looked upon nuts as a holiday diet alone suddenly awakens to the fact that the statement, "nut meat is the real meat," is backed by a public consumption three and a half times as great in I9IO as in 1900 .

Higher education in food values has led people to realize the necessity for different and more varied diet-and this educational development has been facilitated also by economic conditions.

The public forced to cut down on aninal flesh.
As population increases, land becomes more valuable. As land becomes more valuable-intensive farming is practiced. Grazing becomes virtually impossible under such conditions; and despite all the effort of the Department of Agriculture experts, cattle raising is pushed farther and farther from the larger centers of population. Increased transportation and costs of refrigeration mean increased meat prices-even the importation of large quantities of South American beef in the last five years, for instance, has failed to keep meat at a low enough price where it could constitute the large food element which it once was on the American table. 


\section{Nut Meat-The Real Meat.}

Investigation as to food values was the inevitable result.

That this investigation has led to a knowledge of nut meat as the real meat, containing fat and strength-building qualities never before realized-you may judge from the fact that in Igro the consumption of nuts was three and a half times as great as in 1900 -althongh there had been an increase of only $223 / 10$ per cent. in population. Think of it, over fifteen million dollars worth of nuts are imported into America each year; and approximately onethird of that anount is grown here. According to Federal statistics just reported there were $\$ 19,728,924.00$ of nuts imported into the United States during I9I4.

These figures, from U. S. Government reports, show that any one who assumes that nuts are a holiday luxury is entirely wrong. The Pecan, for instance, which is native to America, keeps for a year or more in any moderately cool place without losing any of its flavor or food value. Because Nature put an air-tight shell around the pecan meat-which in the finer grades of paper shell pecans has been developed to a point of perfection not even approached by the best man-made containers.

That public demand for pecan nuts is increasing is proved by the increase of prices on even the commonest sorts of fifty per cent. and more between 1900 and igro.

When J. C. Cooper writes in The Comntry Gentleman for May I, I9I5, that "The demand for walnuts is growing much faster than the supply. We do not produce in America more than twenty per cent. of what we consume, and it will take fifty to a hundred years, with all the encouragement of the nut experts, to raise enough walnuts to supply the home demand," he states a condition which applies with manifold greater force to the consumption of Pecan nuts. It is true that the California production of Walnuts doubled during ten years, while the importation trebled-yet in spite of this five-fold production English Walnuts constantly increased in price.

E. B. Adams, Sec. of Albany, Ga., Chamber of Commerce, furnishes the following table, showing the per cent. of protein in some standard foods:

$\begin{array}{llllll}\text { Pecan } & \text { I9.8 } & \text { Veal } & \text { I5.4 } & \text { Mutton } & \text { I3.8 } \\ \text { Walnut } & \text { I8.2 } & \text { Corned Beef } 14.3 & \text { Chicken } & \text { I } 2.8 \\ \text { Turkey } & \text { I6.I } & \text { Pork or Ham I4.2 } & & \end{array}$

Is there any wonder that pecan nut-meat is replacing animal flesh among people who make a study of food values?

Pecan

nut meata year-round necessity. 


\section{The Finer the Nut-The Greater the Demand.}

Increased demand is for finer nuts.

\section{Paper Shell \\ Pecans} meet every need.
It is true that in Walnuts a condition has come about as in other nuts-that the increasing demand is for the finer, higher priced grades. What are the points of superiority that have led to this great increase in public demand? WTy are old established black wahnut trees less raluable as profit producers than English Walnut trees only a quarter as old and producing only a fraction of the quantity of nuts?

First-Thinness of shell and ability to get out the kernels whole.

Second-Superior flaror and food value.

Third-Attractiveness in appearance of the nut and of the nutmeat when removed.

Fourth-Ease of keeping nuts for longer periods and using them readily.

Now compare the Hess Paper Shell Pecans with the English Walunt on every one of these four points of public demand.

It is contained in a shell so thin that it is easily broken in the hands without the use of nut crackers. The partitions between the kernels arerage as thin as in the English Walnut, and the average person will, in less time, renove more whole kernels of the Paper Shell Pecan than of any other nut.

As to flavor and food value, let such experts as Luther Burbank answer. (See Foreworl, page I.) Remember that his answer is certainly unbiased, for he is a patriotic native of California where Anerica's largest crop of IVahnuts is produced-and that State produces 110 quantity of paper shell pecans.

As to attractiveness in appearance, of both the nut and the nut meat, you and your friends are the best judges. People who know both nuts have already handed in their verdict favorable to the paper shell pecan. In ardition, the pecan has been endowed br nature with a shell which is air tight-and therefore keeps many. times as long without losing its fine flavor or becoming dry and tough.

\section{"The Most Prized of all Nuts for Domestic Uses."}

In Bulletin No, 30 of the Department of Agriculture, Washington, D. C., we read regarding Pecans: "In the course of time, however, as they are more widely grown, they will become the most prized of all the nuts for domestic use, and it is probable that when the supply is large they will be preferred abroad to the best Persian nuts" 


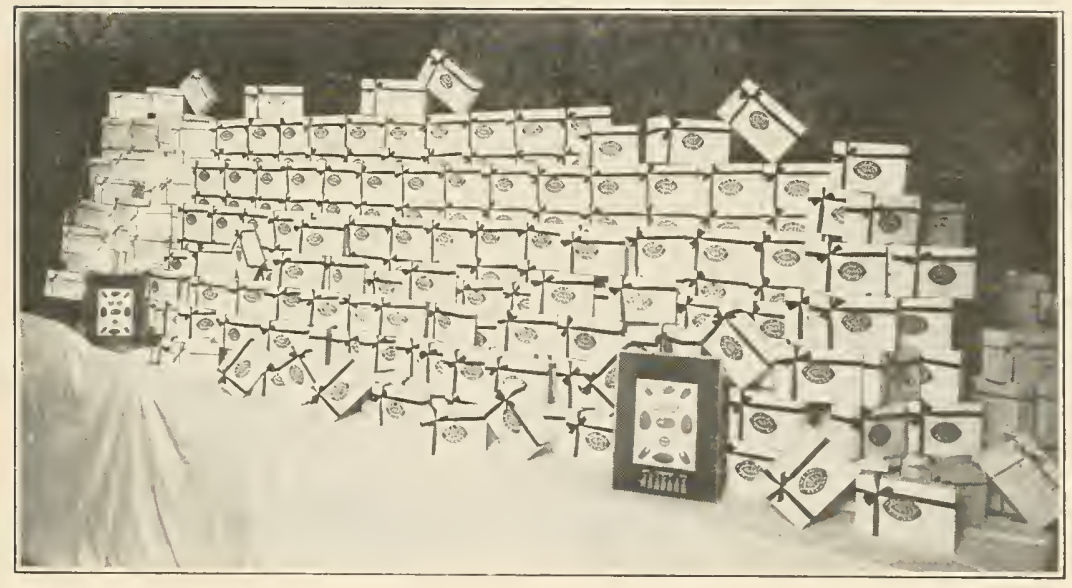

In the Company's Packing Room.

One shipment of Pecans, boxed, ready to send out.

\section{The Pecan-The Year-round Nut.}

The pecan is the one nut suitable for eating the year round. And the present tendency is toward the year-round use of nuts.

Another reason why the finer pecans are surer to maintain their high prices than any other nuts is found in the fact that Wahnuts of the finest grades are being raised in quantities in California, Oregon, Washington and other States, and in England. France. Italy and South American countries-while the territory in which the paper shell pecan attains to its highest state of perfection is confined to a 40-mile radius in southwestern Georgia, embracing Calhoun and Dougherty Counties.

Is it any wonder that the State Entomologist of Georgia, Mr. E. Lee Worsham. whose name is virtually always included as one of "the three big men in his line of endearor," wrote: "In my opinion the pecan growers of South Georgia have the finest horticultural proposition in the United States."

\section{"A Greater Future Than Any Nut Raised in this Country."}

"It is not many years since these delicious nuts, the Paper Shell Pecans, were first introduced to the people of the North, and wherever they have gone they have met with instant and cordial favor. The Paper Shell Pecan has a greater future than any other nut raised in this country. It is a most delicious nut." Geo. K. Holmes, Lnited States Bureau of Statistics, Washington, D. C.

\section{Can be} raised at best, in a 40-mile radius. 


\section{"What is the Paper Shell Pecan?"}

Mention Pecan to any one who has tasted the improved paper shell variety and they will assume that you are talking of paper shell pecans. For the person who cracks and eats paper shell pecans feels it almost a sacrilege to call the common wild pecan a pecan. let there are thousands of Americans who have never tasted paper shell pecans, and who think of pecans only as wild pecans, grown largely in Texas.

Pecans are divided in three general but radically different classes, as the descriptions and cuts below indicate.

Wild Pecan-a staple food among Indians.
The ordinary wild pecan is native to America. The earliest French explurers found that one of the staple foods of the Indians

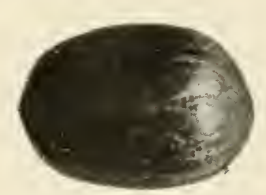
was this palatable nut which grew in the forests of the south, and in that portion of Mexico adjoining the Gulf States. Pecan trees 11 Texas and Louisiana have been found which were over five hundred and seven hundred years old -which were still yielding large crops of nuts.

Like the vak, no one ever knew a Pecan tree to die of old age.

There are in the Southern States wild pecan trees of which the records go back to the first civilization on this continent.

The pecan tree is so symmetrical and beautiful that it is called "The Queen Shade Tree of Nany a Southern Home." Its fruitage is so prolific that it is said to be "one of the most astonishing food engines in all nature, yielding literally barrels of nuts"

\section{From an Eminent Writer on Food Values.}

"Being almost entirely a non-flesh eater, I have for sixty years been a connoisseur of nuts. I have sampled many varieties, from the filberts and cob nuts of Kent to the almonds and "English" walnuts of California. And in between I have tried nuts of many countries and many climes. I must say that Hess paper shell pecans are different from, and superior to, anything in the nut line I have ever eaten, with a single exception, the Kentish filberts. They should be a boon to fruitarians." H. B., Los Angeles, Cal. 


\section{The Hardiest of all Nut Trees.}

The reason for this long life is that the pecan is the hardiest of all nut trees--free from all ordinary tree pests and diseases because it is of the hickory group, and the longest lived member of that group. The lack of surface moisture-the great enemy of most trees-is not a clisadrantage to the pecan, for it las a remarkably long tap root which goes down so deeply into the ground that it draws moisture from the sub-soil. Since the blooming period is late in Spring, the buds are not injured by frost.

The wild pecan has been a popular nut. rivaling, because of its superior flavor, such other nuts as the walnut, chestnut, shell-bark, hickory-1ut, etc. This popularity was secured despite its many drawbacks - for the shell of the wild pecan is hard and the partition walls between the kernels thick and bitter. There was too little meat and too much difficulty getting it-but the experts saw in the great demand for pecans, despite these disadrantages, the promise of rich reward for improving the pecan.

The seedling pecan is the next step toward pecan perfection. Larger than the wild pecan, and thinner shelled, it equals or surpasses it in flavor, dependling upon the variety of seedling under consideration. Selling at an average price of thirty to forty cents per pound, which is dentle the cost of the wild

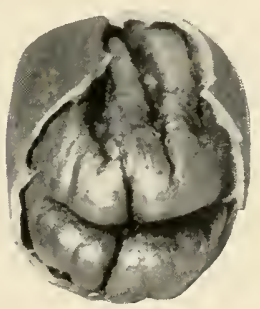
pecan, it has so much more meat and it is much more accessible, that it is alwars a better paying purcliase for the housewife. So justly popular has the seedling pecan become that the discriminating dealer and the discriminating housewife will have nothing to do with the inferior, thick-shelled pecan, which is brightly tinted and polished to disguise the inferiority.

\section{Surprised at the Size of Kernel-and Flavor.}

"I have received the 22-ounce box of Hess High Grade Seedling Pecans which I ordered from you a few days ago.

I am well pleaserl with the nuts. They are certainly worth the price, and then sone. On opening the nuts, I was surprised at the remarkable size of the kerneis within, and of their delicious, sweet, nutty flavor. Your Pecans are par excellent! They have, no doubt, a very ligh food value, and I intend in the future to omit meats from my diet and substitute your Pecans instead. It is remarked by cminent physicians that much of the cancer that is presalent now'adays is due to the excessize consumption of meats, and that the only remedy is for people to gir'c up the cating of meats and use nuts instead.

I expect to favor you with additional orders in the future." J. P. F. Roanoke, Va.

Pecan trees fear no drought.

\section{Seedling} superior to wild grown Pecan. 


\section{The \\ paper-shell \\ Pecan-the \\ Queen of all \\ nuts.}

\section{The Paper Shell Pecan.}

Had the work of the experts not gone any further than establishing the improred Pecan Seedlings, it would have justified all their efforts-for the pecan seedling bore justifiable comparison with any other nut on the market in food value and accessibility; nutil the Paper Shell Pecan was developed from budded trees.

The Paper Shell Pecan has an air-tight shell so thin that it is easily broken in one hand by a gentle pressure. The kernel is large, easily removed and of flavor so much finer that any observing person can distinguish it from any other pecan by taste alone.

Instead of a bitter partition wall which imbeds itself in the nut when it is cracked, as in the wild pecan, the paper shell pecan has a thin, tissue-like membrane which is easily remored.

With the paper shell pecan a larger portion of the total weight of the nut is meat than with any other nut, with the possible exception of the finest almond. And this meat of the paper shell pecan contains serenty per cent. fat, while that of the alnond contains but fifty-four per cent.

The paper shell pecan is the Queen of all nuts.

It has no equal from the standpoint of size, appearance, accessibility of meat, size of kernel, and fine flavor. The only disadrantage is the limited supply-for there is but a small territory in which soil conditions and clinlate are right. The wahnut is raised in England, France. Italy and in large quantities in the three Pacific coast states, and in smaller quantities elsewhere. The paper shell pecan seens to flourish hest within a forty-mile radius in Georgia, embracing Calhoum and Dougherty Counties. Of the half million budled pecan trees in the world, two hundred and forty thousand. or practically half, are in this forty-mile radins. Were complete records of yield accessible, it would be seen that this lialf of the budded trees has produced far more than their portion of the crop.

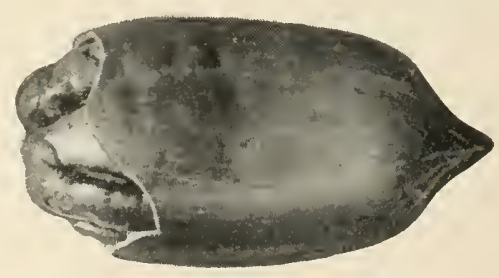

The State Entomologist of Georgia. Mr. E. L. Worsham, writes: "The Pecan Industry has developed beyond the point where it matters not what you or I believe. It is a success. Results are being produced of wide interest and of permanent character, and the industry in the Albany district in the hands of competent men has wonderful potentialities. The hundreds of thousands of dollars invested by shrewd business men in Commercial Pecan properties, after personal investigation, argues that the development being recorded in the Albany district is meritorious." 


\section{Hess Paper Shell Pecans.}

It is never difficult to convince any one who has tasted the Hess Paper Shell Pecan, and compared it with the other pecans, why the paper shell pecan should be selling for eighty cents to \$r.25 per pound and up, when the wild pecan is selling at fifteen to twentyfive cents per pound. The only difficulty is that not one person in a thousand has ever tasted the improved Paper Shell Pecan, because the supply is so small compared to the demand.

As Luther Burbank, adnittedly the foremost horticulturist in America, has well expressed it, "We have now one Pecan where we ought to have a million to create a market. The demand for them is constantly increasing, and the price is advancing each year, for the demand is many times greater than the supply."

The Hess Paper Shell Pecans are selected varieties of the Paper Shell Pecan, grown and developed in the Pecan Belt of Georgia by expert horticulturists. These experts, who have made Pecan Culture their life work, succeeled after expensive experinentation in developing the Hess Selected Varieties from the Stuart and the Schley Pecans, which were accepted as standards of high quality by the National Nut Growers Assnciation. The Stuart and Schley are naturally hardy, rapid growers, which will live for centuries because of their resistance to fungi. destructive insects, cold and drought. The Hess Selected Varieties combine with these advantages of the Stuart and Seluey a purity of strain which assures uniformly superior pecans.

Note the color plate on cover, photographed from arerage nuts of the improved Hess Selected Varieties of Paper Shell Pecans. The large size of the nuts, the thinness of the shell, the almost entire elimination of the center partition, the finer flavor and the greater food value put these nuts in a class by themselves for quality. Do not take our word for their superior quality. Note what others say about Hess Paper Shell Pecans.

\section{"Cover a County with Trees," to Supply Demand.}

"Your shipment of 'Paper Shell Pecan Nuts' reached my house yesterday, so we had some of them with our coffee at dinner. and I take pleasure in confirming all you claim regarding the size and quality of those nuts. They are certainly superb, and a revelation of what specializing may accomplish in that line.

Now what you want to do is to cover with such nut trees a whole county in the most farorable part of the South for the purpose, so as to give the people an ample supply, and I will guarantee they won't go far for any other nuts." L. F. S., Ridgewood, N. J. 


\section{The Highest Priced Pecans-Yet Demand Exceeds Supply.}

A ferv

commendations from many received.

Re-orders and the cash-prove superiority.

Advance orders accompanied by cash.
A high official of the city of Nerr York wrote: "Such pecans never were seen before in our neighborhood. They are all you advertised then to be. I sent a box on to my danghter in Boston."

From a Philadelphian who "knows nuts," we heard: "The Hess Pecans, which terminated our Nmas Dimer, were highly appreciated. Being a lover of Pecans, I must say that Hess Pecans are far superior to any other Pecans I ever tasted; especially the Paper Shell kind found great faror among my guests."

From another, whose husband is at the head of a publication which enjoys national prestige as an exponent of the finest nuts and other foods by mail order, we received the following letter, along with the second order: "Enclosed find check for \$2.00 for which send me a 22 oz. package of your Paper Shell Pecans. Kindly ship these at once as we wish them for Thanksgiving."

Why take more time with detailed copies of letters from customers ordering and re-orlering Hess Paper Shell Pecans. Is not the fact that re-orders were received in itself the best evidence of superior quality when it is considered that the selling price of these nuts was $\$ 2.00$ for 22 ounces, or about the rate of $\$$ I.5O per pound?

The man whose wife wrote the last letter questioned whether any one would pay this price-for an addition of fifty per cent. of the price of the average paper shell pecan was too much, in his opinion. He questioned the price before he sampled the nuts and noticed how nuch they were preferred in his own home and among his friends. After that the price was forgotten and the recollection of superior quality led him to re-order, just as it did many others.

The few checks shown on page fifteen in this book tell an eloquent story of orders and re-orders-it is, of conrse, possible to show in this manner but a fraction of the cases in which re-orders were secured.

Those who taste Hess Pecans no longer consider then a luxury. Their delicions flavor and their remarkable food value make them such a necessity that immediately after last season's crop was exhausted, advance orders began to pour in upon us. A large percentage of these were accompanied by cash in advance for increased quantities of Hess Pecans.

\section{Hess Paper Shell Pecan "Everything You Say It Is."}

"This is to acknowledge receipt of your kind favor of the 6th, and also the box of your very fine pecans. Jour product is certainly everything you say it is, and we are enjoying them rery much." G. H. P. Co., Battle Creek, Michigan. 


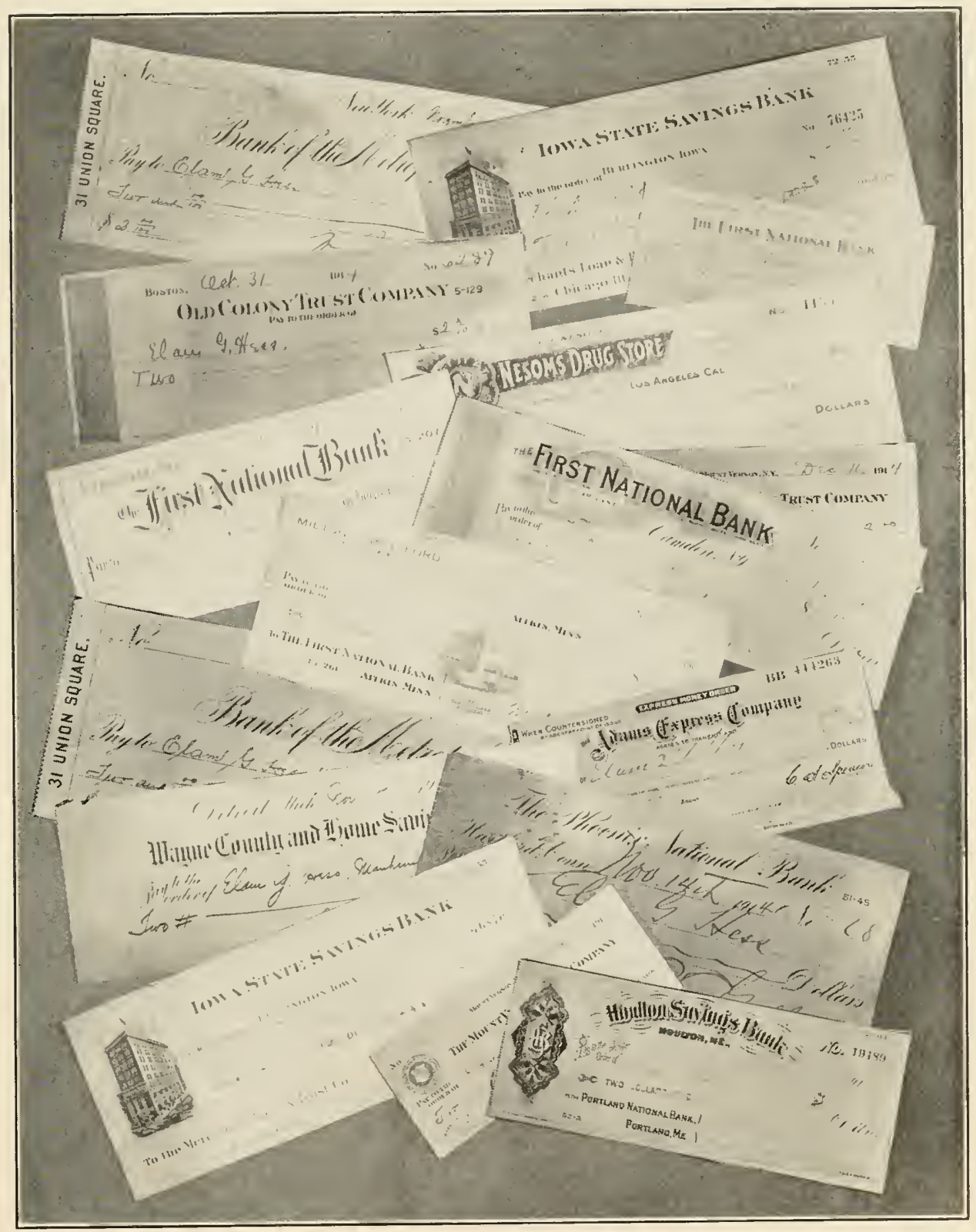

A few checks received in resfonse to our advertising of Hess Pecans. Continuous demand on a cash-in-advance basis proves superiority. 


\section{Tons of Nuts Were Sold by Us.}

\section{An unique Christmas gift.}

\footnotetext{
Nezw York City can consume the world's supply.
}

during the past year. Not all of these were the Hess Improred Paper Shell Varieties-because practically our entire supply of these was sold ont over the Christmas and Holiday season. The demand exceeded our most sanguine expectations-the number of $\$ 2.00$ boxes sent out as Christmas gifts being greater than we had expected to sell in November. December and Jannary combined. Some purchasers have bought from us by mail as often as twelve times during the past winter-which record was probably surpassed frequently by dealers handling our Pecans.

On page nine you will find an illustration showing one shipment of Hess Paper Shell Pecans-boxed ready to send ont.

In one average American city of only 5 I, ooo poptrlation (basecl on the Igro census) the sales of Hess Paper Shell Pecans through one wholesale grocery firm astounded us by their volume. The same grocery salesmen who considered it a "joke to attempt to sell such fancy nuts" came back with orders from stores of all classes in all parts of the city. Even in the poorer sections the grocers ordered and re-ordered till the stock of the wholesaler was all gone and we could supply him no more of this finest grade pecan-for our total supply had been exhausted.

For prices at which these pecans sold, see letter. pages $+t$ and +5 .

The city in which this test was made was not onr home town. It does not stand above the average in per capita wealth-nor is there any eridence to show that the people of this city are more likely to be interested in pecans than any arerage Americans. To make such a test in a large city like New Jork was impossible-for the entire yield of onr entire plantation, planted twenty trees to the acre, could not supply a week's demand there, if New York bought pecans in the same proportion as the city cited abore.

We must take immerliate action to increase the quantity of Pecans offered for sale.

Even with the wonderful increase in yield each year from established orchard minits. we cannot fill half as large a percentage of the demand as we did two years ago.

The Country Gentleman, of September I9, I9I4, says: "Tyler is a Texas town with abott I2.000 people who eat a carload of pecans every year. If New York ate Pecans at the same rate, it would consume our * whole crop." (This * our refers to all the world's crops combined.) 


\section{Why This Phenomenal Demand for Finer Pecans?}

How can this remarkable demand for the finest srate pecans - despite the higher price-le alcombed for :

There are many reasons:

This remand for perfect pecans parallels an increased demand for nuts of all sorts-pecaus in particular.

As any well informed person knows there is strongly in eridence all over the worlel a mosement toward nut meat ats the true meat.

Some bate joined in this for religions reatsms, some for ethical reasons, and others purely from dietetic or hygienic comsiderations.

A countrywide moyement toward nutmeat as the "true meat."

The Seventh Day Arlventists will refer you to the twentyninth rerse of the first chapter of (ienesis, which reads. "And ford said, behold, I have given you every herl, bearing seerl, which is npon the face of all the earth, and every tree in the which is the frowit of a tree yielding seed: to you it shall be for meat." They reason that according to this passage "true meat" grows on trees. and in this belief they are joined by many others for ethical, dietetic ancl hygienic reasons.

The Tillennim Cuikl, which has at small but active mentuerships of thinking people in Bostone is typical of these ethical movenents which have assumer great importance in parts of burope. While they batse their preference for nut meat on ethical rather than religions gromuls, the members of these organizations simply abbor the ilea of eating the carcass uf amy animal.

Evergwhere in America there are large numbers of people organized and monorganized, who will not eall the flesh of any animal for rlictetic or hygienic reasoms.

Physical Culture restaurants, where nut meats are sulstituterl for animal flesh, are increasing in number in every large city.

In sanitaria of all sorts there is a tendency to minimize the use of animal meat or do away with it entirely. In one system uf forty sandaria, there are practically no drugs used lecause the patients are put on a perfected diet system in which nots are sul)stituted for animal flesh.

\section{Hess Pecans are Rich in Nutriment.}

"They are certainly acry fine nuts, and I an very grad to kiuow about them. As to their food value, I have ne dould they are rich in nutriment." A. G. D., Brookline, Mass. 


\section{Nuts Meet the Demand for Uncooked Foods.}

Many physicians who specialize in diseases of the intestinal tract are advising the use of uncooked foods. Nut meat is practically the only source of both protein and fat in large proportions, which it is safe to eat moooked.

Eren these canses, which are so readily apparent, hardly account for the fact that the consumption of nuts in America had increased in I9lo to three and one-half times the amount consumed in I900: while the consumption of animal meats failed to keep pace with the increase of population during this same period.

Less

butter-fat demandedmore nut-fat.

Pecan tree nature's most pozverful food producer.
Possibly you will find this increase in the consumption of nut meats eren more surprising when you consider that there was practically twenty per cent. less butter sold from America's farms in Igog than in I S99, according to U. S. Census figures. In other words, the consumption of butter, which is the principal table article competing with nuts in fatty content, was falling off to four-fifths during practically the same perior that the consmmption of nuts was increasing to three and a lialf times its former figures.

Perfecterl pecan nuts contain more protein than beefsteak, and almost as much fat as butter. Isn't it only natural that people should want their nourishment and fat in this concentrated formhermetically sealed and kept pure by nature? Is there any such assurance of purity and cleanliness-on butter-or on beefsteak?

Place a Hess Pecan on a hat-pin, light the nut-meat and notice that it burns like a candle because it is seventy per cent. fat.

The Conntry Gentleman, in an article on Pecans, published the following: "The nut is nutritions, very nutritions, and we already have numerous instances of one good big tree making more human food than the best acre of blue grass in all Kentucky. Plainly, the tree-nut method beats the grass-meat method of feeding man. Tree crops are to be the agriculture of the future."

\section{Delicious in Taste-Will Order Again.}

"I am a reader of Health Cuiture Magazine, and a great lover of good Pecans. Seeing your ad. in Health Culture Magazine about Seedling Pecans, I have decided to have you send me a $12 \mathrm{lb}$. carton for which please find enclosed my check. Kindly send same at your earliest convenience and oblige." J. J. IV., Jr., Cincinnati, Ohio. (First purchase was 12 pounds.) 


\section{Pecans for Sundaes and Candies, Etc.}

The young women of America. who have changed so largely from soda water and ice crean to nut sundaes, may not realize that they are getting increased nourishment-but that is the case. That this is no small element in the consumption of pecans is evidenced by the fact that one druggist alone uses I,500 pounds of crushed pecan meat per year for nut sundaes - while hundreds might probably use as many if the true figures were known.

Nut candies are in such great demand that the best confectioners are astonished. Unfortunately for them, certain nuts become unfit for use in sunnmer and the confectioner must fall back on the homely peanut. which falls short in food value, or use the pecanthe finest of nuts. which nature has furnished in an air-tight shell, which assures satisfaction the year round. The confectioners of New Orleans-a hot weather city-long since learned their lesson and that city is almost as much noted for its pralines-a pecan nut confection - as for its wonderful fete, the Mardi Gras. Pralines were too good to be confined to $\mathrm{N}$ ew Orleans alone. A $1011 \mathrm{~g}$ the boardwalk in Atlantic City and other watering places; and at the finer confectionery shops of the larger cities, they are in good demand. There is

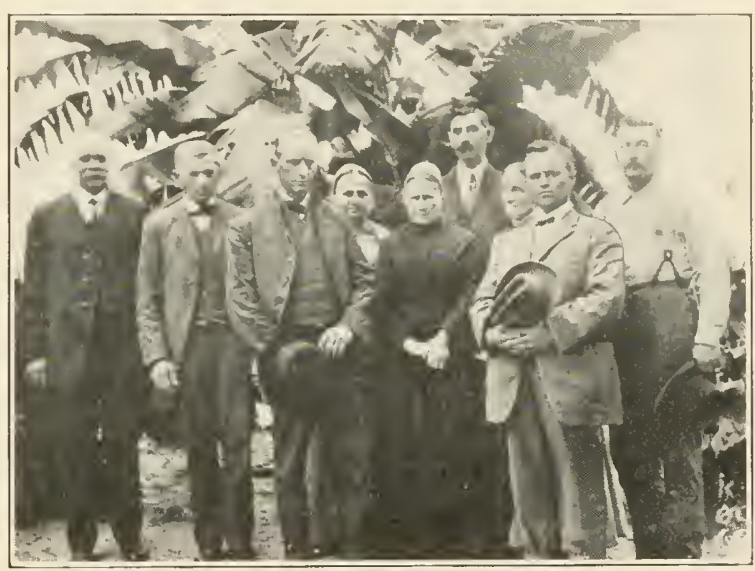

Enos H. Hess and Vice-President, Jos. A. Philips, Director and some stockholders on the Keystone Pecan Plantation. no other way to make acceptable pralines except by using pecan nuts - the finest pralines require that the nuts be whole, which, in turn, indicates another need for paper shell pecans.

From the President of the Albany, Ga., Chamber of Commerce, J. A. Daris. we hear: "The strongest evidence of my belief in the future of this wonderful development is that I have just planted a grove of one hundred acres. I know of no agricultural or horticulturai industry which with proper attention holds promise of returns half so large as the pecan in Sonthwest Georgia. Both our soil and our climate are peculiarly adapted for the production of the finest nuts in most abundant yield. These nuts are the size and quality which make them absolutely the finest nut on the market. They will always conmuand a fancy price because the supply will never equal the demand." 


\section{Maximum Food Value-in Condensed Form.}

Greater digestibility.

Convenient, condensed nutriment.
One remarkable fact about the improved paper shell pecan is that it is at the same tine richer in protein and fat than other nuts; yet is more digestible. People who say, "I cannot eat nuts because I suffer from indigestion," are surprised to hear of Pecans being prescribed by phrsicians-mutil they try the paper shell pecan thenselves and find that it agrees even with the invalid. Unlike other nuts which contain less fat-it can be eaten in quantity without salt, withont any ill effect. This is probably due to the fact that the improved pecan contains an oil which seens to possess many of the lubricating and healing qualities which are found in olive oil.

The digestibility of Pecan fat is an established fact-pecans are used largely at such scientifically conducted sanitaria as those at Battle Creck as a substitute for meat and corrective diet in troublesome cases of intestinal derangement.

Consider the many fortunes made in olive oil-then remember that even if scientific research should show that the pecan is not so beneficial as olive oil, it has many manifest adrantages in its more appetizing form, assurance of cleanliness and purity, etc., which make its future promising.

No authority has ever questioned the nutritive value of the pecan. Even the wild pecan, which is far inferior in nutritive qualities to the paper shell pecan, has met with the highest recommendations from eminent authorities. But the fact that this nutriment was locked up within a hard shell, separated by a partition so strong and bitter that it was seldom possible to get out a satisfactory kernel, kept the wild pecan from enjoying the wide popularity it desired. The introduction of the improved seedling and paper shell varieties not only led to an interest in these improved varieties, but caused such an increased remand for all pecans that prices rose on even the poorest wild pecans. But the public found that the cheapest pecans are the dearest in the end-and the demand for pecans has increased most rapidly on those grades from which the largest kernels, containing the utmost in nutritive value, could be removed whole.

\section{A Fine Oil-But Not Enough Nuts.}

"According to analysis, the Pecan is richer in fat than any of the other nuts, zo per cent. of the kernel is fat. The Pecan may at some time be in requisition as a source of oil - an oil which would doubtless be useful for salad purposesbut it is never likely to be converted into oil until the present prices of nuts are greatly reduced." Prof. H. Harold Hume. Florida State Horticulturist, Glen St. Mary, Fla. 


\section{A Test Which Proves the Best Pecans Cheapest in the End.}

The willingness of the general public to pay the maximum price for Hess Paper Shell Pecans can be attributed only to the fact that this improved variety of Paper. Shell Pecans gives more in return for More value for every dollar spent. every dollar invested. You can prove this to your own satisfaction by comparison with any other pecans at any price.

There are five representative classes of pecans which should be considered in any test; below is a report on a test made of equal weights of all five grades. We have stated opposite each the retai arerage selling price generally secured for that grade pecan, although on Hess varieties we have secured higher prices by our inproved merchandising.

First. Common wild pecans sell at about 22c. per pound.

Second. Common seedlings sell at about 28c. per pound.

Third. Hess Selected Seedlings, at an arerage price of $35 \mathrm{c}$.

Fourth. Common Paper Shell Pecans retail at an average of about 75 c. per pornd.

Fifth. Hess Paper Shell sell at \$I.oo per pound and up.

The results of a careful comparison of these five grades, using an equal weight of each, disclosed the following facts:

A-Before Cracking.-Though size of the nut whole counts for but little in judging pecans, as compared to the quantity and quality of the meat within the shell; those making the test were interested to note that arerage Hess Paper Shell Pecans were exceeded in size only by a few of the largest pecans in class fourother varieties of paper shell pecans which were later found to have large shells only partially filled with meat.

It was noted that the brightest looking nuts proved in the end to be the poorest quality-for the cheapest wild pecans are dipped in varnish to make them look attractive.

B-Opening Process. - The Hess Paper Shell was found to open more readily in the hand without nut crackers, than did the other classes of nuts when nut crackers were used. When the fragments of shell were compared it was easy to see why-superior thinness of shell distinguishes Hess Paper Shell Pecans.

The neat in the Hess Paper Shell Pecans filled the shells completely, while large air spaces were noted in many other varieties.

\section{“Why are They So Different?” Sun Ripened.}

"You cannot say too much for the Hess Pecans. I an delighted with them. They are by far the most delicious muts I have ever eaten. I am quite interested to know how you grow them and why they are so different from other Pecans. I have eaten Pecans from near Evansville and Mount Vernon, but the ones you sent are far superior in flavor and thinness of shell." G. H. H., Ravenna, Ohio.

\section{A test which shows why.}


C-Separating Meat From Shell-When the various lots of nuts were carefully opened, in separate piles, a careful comparison was made of the meat and shells in each pile.

The number of whole kernels was counted-no other pecan had four-fifths as many whole kemels as were found among the Hess Paper Shell Pecans. The common wild pecan and the common seedling had such hard shells that the meat was practically all broken to small fragments in opening the shells. No detailed comparison was necessary between these crumbs of nut meat, mixed with shell and pith, and the whole kernels or half kernels of the Hess Paper Shell Pecans.

D - The Pith Test - In the Hess Paper Shell and the fourth variety-which costs nearly as much per pound-there was practically no pith - the partition taking the form of a thin membrane which was easily removed instead of the thick, bitter wall of the two cheaper pecans.

E-The Final Test-When the nut meat, which was in appetizing or edible form, was separated from the shells and partitions in each case, it was found that for table use the Hess Paper Shell gave the greatest weight of nut meat for every dollar invested in the nuts, carriage and opening costs included. The conmon paper shell variety which cost nearly as much as the Hess Paper Shell was a poor second, followed closely by the Hess Improved Seedlings, while the two cheap grades were in the end the most costly investment - because they yielded so small a quantity of satisfactory nut meat for each dollar invested.

This is also confirmed by many other tests, which show that even including small particles of nut meat. which are far from appetizing in form, the wild pecan and the common seedling yield less than four pounds to each ten pounds of muts; the Hess Seedling Pecan and the common paper shell about five pounds to each ten pounds, and the Hess Paper Shell Pecan about six and three-quarters pounds of meat to each ten pounds of nuts.

IVith such superiority proven for Hess Paper Shell Pecans, it is no longer a question whether the public will pay the higher price. The question becomes rather, "Can the public afford to pay less for any other nut, and get less value for every cent paid?"

\section{"The Finest Flavored Pecans Ever Tasted."}

"The box of High Grade Seerlling Pecans came ali right and we find them all that your advertisement represents them to be. They are good size and nearly meat-almost no shell. Very nutritious and of a flavor far exceeding the ordinary Pecan. Our friends, without exception, pronounce them the finest flavored Pecans they ever tasted." E. B. P., Melrose. Mass. 
That the public measures Pecan values rightly is proven by the remarkable success of our sales on Hess Paper Shell Pecans in the past. Our only problem now is to meet the demand for these lighest grade paper shell pecans and for the innproved Hess Seedling Pecanswhich are by far the best investment for the houserife who uses pecans for baking, candy-making, salads. nut filling, etc.

It is simply narvelous how hungry the world is for these fine tasting Pecans, and it will be lunngry for many years to conle because the increase in supply does not keep pace with the rapidly increasing demands for ligh quality Pecans. The present problen, therefore, is to produce more fine Pecaus by planting more Pecan trees.

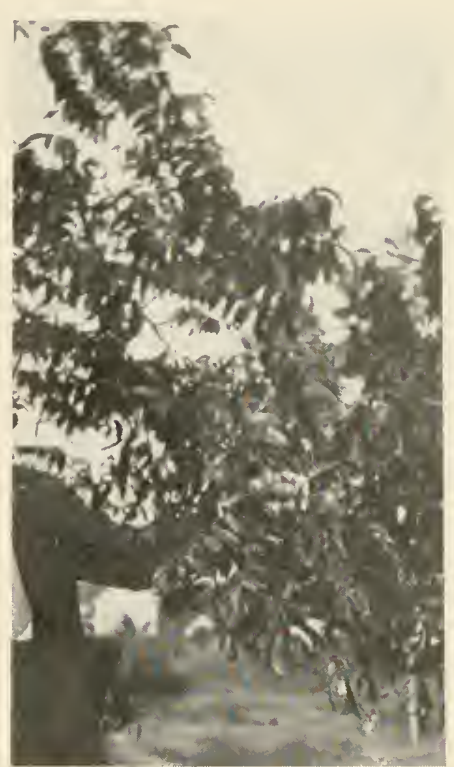

Ten pecan nuts in one cluster, of which seven can be seen in cut. The man in picture is Mr. Thos. F. Miller, of Allentown, $\mathrm{Pa}$., who visited the orchard in 1913 with Mr. B. L. Johnson, of Allentown, by whom this photo was taken.

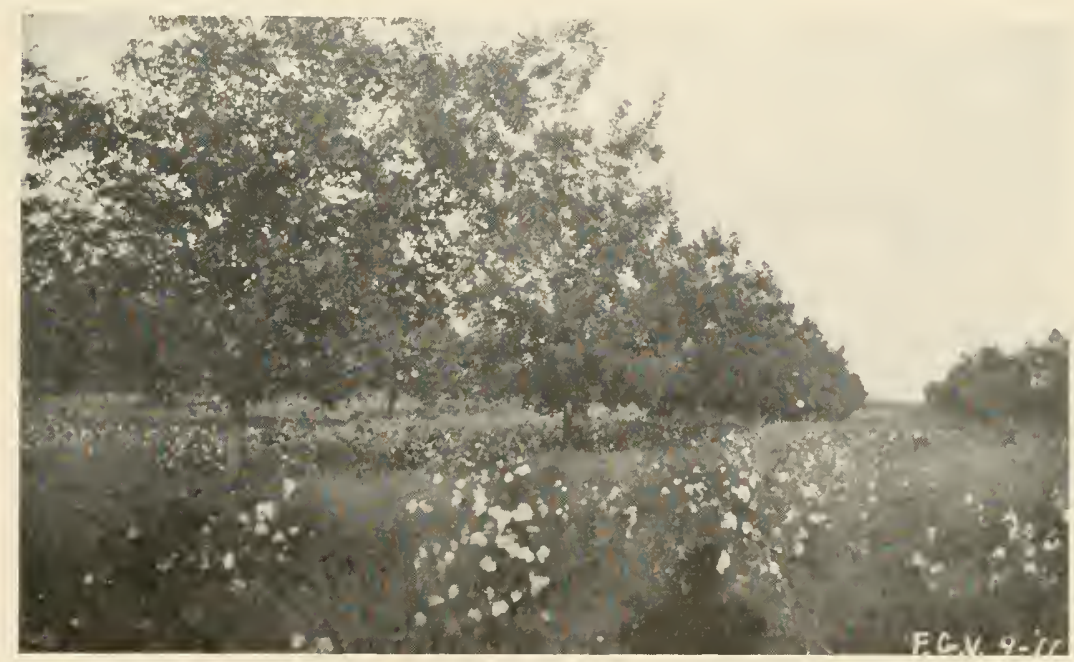

View in an eighty-acre pecan nut orchard, near our plantation, for which the owner refused eighty thousand dollars.

\section{Full of Meat - A Strong Point on Hess Pecans.}

"The meats were full and of the finest flavor. Possibly the best recommendation I can give is to enclose herewith my check for which please send me i2 pounds of pecans as advertised. I would be pleased to know what part of the South these nuts come from." H. G. S. Pittsburgh. Pa. 


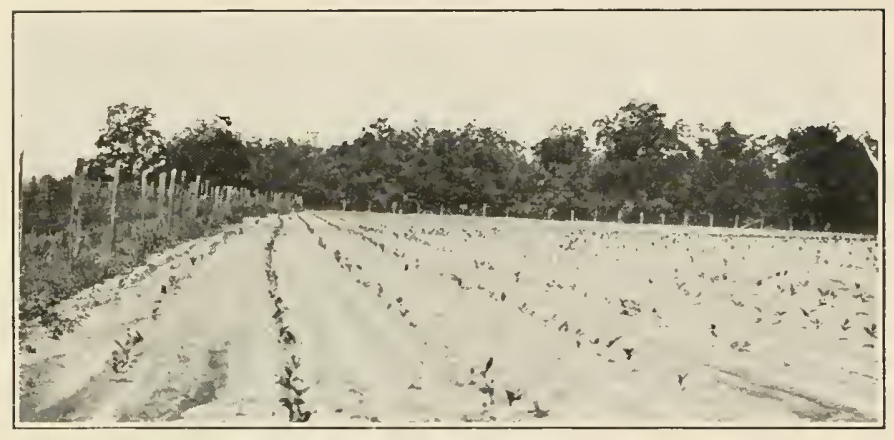

A corner of the Nursery

in which our young trees are grown. In the distance, our seedling orchard which is bearing profitable crops. (Above photo taken May, 1912.

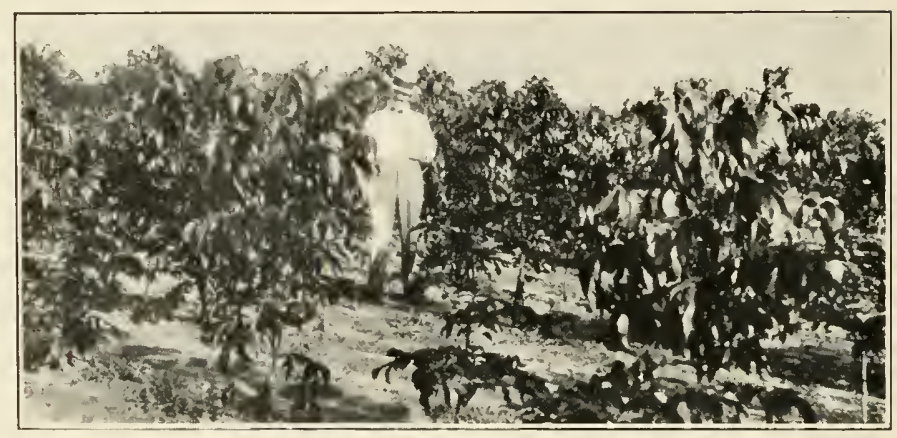

Two years later in the same nursery corner.

Mr. George Bollinger, of Allentown, one of our orchard-unit holders inspecting the nurseries in 1914. Note the size to which two-year-old trees have grown.

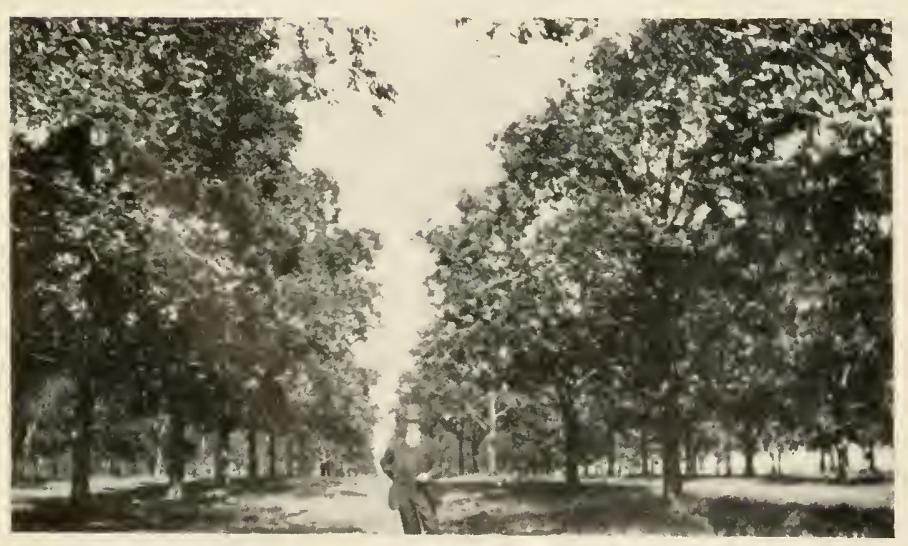

Another section of pecan orchard on our plantation after cultivaticn. Note the sturdy growth of these young trees by comparing with height of man in foreground. 


\section{The Big Problem-Establishing More Orchard Units.}

Like all tree crops of ralue, pecans do not bear the first conple of years after planting. It is during this period before bearing begins that care and attention are necessary-once well established. the Pecan is hardy as an oak.

We have in our nurseries many budded trees of those two proven valuable varieties on two or three years' root, waiting to be set out in orchard units - the average size of these trees being three to five feet higl.

We own 2.873 acres of fertile land in Calhoun Comnty, Georgia -which has been examined by experts of highest standing and approved by such men as the government expert as of the rare character of soil necessary to produce finest paper shell pecans.

Corroborating these opinions is the fact that we have right on this property many pecan trees, bearing nuts in large quantities, despite the fact that they were planted thirty trees to the acre some twenty years ago. Now only twenty Hess Paper Shell Pecan Trees are being planted to the acre, because of their vigorous growth. These trees will undoubtedly increase in size and in annual yield every year till they are forty years old - and bear their maximum crop for a century or more.

The Keystone Pecan Company was organized and incorporated for the purpose of planting its property with Paper Shell Pecans on a co-operative and profit-sharing basis-that is, of the 2.873 acres. I, 800 acres will be sold to investors, the investor buying as few or as many acres as he desires, the company plants the property to Paper Shell Pecans of standard rarieties, twenty trees to each acre. It cultivates and cares for the trees and the land for a period of five years for $\$ 300.00$ per acre, on easy payments. After the five year period the company shares with the unit holder in the profits from the units as explained on the following page. Our unit plan is considered by conservative investors as the safest, most equitable and most profitable plan to plant onr large Pecan plantation in the shortest possible time.

H. A. Halbert, Coleman, Texas, says: "I consider the Paper Shell Pecan industry the safest, most profitable and lasting of all the industries that spring ont of mother earth. I never had a Paper Shell Pecan tree yield me more than $\$ 253.25$ in one year, and never less than \$10. per tree after the native trees have been buddedl five years to Paper Shell Pecans."

More orchards a vital necessity.

Co-operative and profitsharing system. 
All trees that die replaced without charge.

Crops marketed for you.

Sold on easy monthly payments.

You ozen the land.

\section{We Sell You the Land and Farm it For You.}

Under this attractive plan the company agrees to sell to investors land up to $\mathrm{I}, 800$ acres out of this plantation. The interest of the company and its obligation to the investor does not cease with the sale of the land, for the company binds itself to planting, and is planting: not less than the full r.Soo acres of land with Paper Shell Pecans of the finest standard rarieties-the Hess Paper Shell Pecans-twenty trees to the acre.

The company further obligates itself to do all the cultivating necessary-caring for the young trees and the land for a period of five years. replacing at its own expense all damaged trees, and guaranteeing that at the end of the fire years all trees will be in a healthy, thrifty condition. All this is done without expense to the buyer. The profits from any nuts grown during this period will be paid to the Lnit Orchard owner after deducting I 2 I/2 per cent. commission for gathering and marketing.

After the expiration of the five-year period, the company is to continue to operate the property on the most profitable basis. fertilizing and farming the land, cultirating and pruning the trees. as well as gathering and marketing the pecans, and will receive for this service $\mathrm{I}_{2} \mathrm{I} / 2$ per cent. of the profits: $8 / \mathrm{T} / 2$ per cent. being paid to the Lnit Orchard owners. Lnder the agreement and plans as outlined there will be enormous profits.

Is the expense of developing will be distributed orer a period of fire years, the Company has arranged to sell the Orchard Units on small monthly paynents, thus placing a golden opportunity within the reach of the inrestor of moderate means and giving him a chance to make his sarings and surplus work for him as effectively as though he had a large amount of capital.

You becone absolute owner of the acre of land in your orchard muit. The land is cleared from trees and stumps, the Pecan trees are planted, cultirated and cared for as a whole on a large scale. This is co-operation under a system that relieves you of every worry and which makes for economy and large profits.

\section{One of the Best Possible Investments.}

"We also wish to express our confidence in the Pecan industry: We believe it to be one of the best possible investments. This locality (The Albany District) is especially farorable as to soil and climate conditions necessary to the lest results." S. B. Brown, President Exchange Bank, Albany, Georgia. 


\section{The Practical Answer-the Unit Plan.}

There are many people who know of the great successes made in Pecan growing in this district. who wonld be glad to buy five. ten or twenty acres of our Pecan Plantation. The land in itself wonld undoubtedly be a good investment, becanse cases are on record showing increase of donble and treble value on land which did not have a bearing orchard. But this would not be of any great advantage in solving the problem of supplying more of the finest pecans unless the purchaser had the knowledge, skill and time to bring his trees to the bearing point.

Even assuming that he conld bring the trees to the bearing point, his ability to market his product advantageonsly could not possibly equal that of a co-operative group of orchardists, who have the most skilled supervision service and the arlvantages regarding marketing which cone from collective effort.

IVith several carloads to ship instead of a few barrels, the large orchardist is in a position to command the very lowest rate and to reach the market in just the right season.

Ask any member of the Citrus Fruit Exchange whether he has made more money since he joined those organizations than he did before, and he will tell you an interesting story which cannot fail to conrince you of the advantages of collective marketing. Iet oranges and grape fruit, the products of the members of those exchanges, are perishable in such a short time that they derive the benefits of but a fraction of the crop compared with the Hess Paper Shell Pecans.

There are other advantages of collective effort which exceed even the adrantages in marketing. Among them is the advantage of skilled supervision at minimum cost. The professional or business man can live in the North, enjoying the incone which his specialized efforts assure, yet be growing his pecan orchard in the Sonth under the superrision of expert pecan horticulturists, whom he conld not possibly afford to retain for a plantation of less than a thonsand acres, with labor costs minimized as a result of such skill ful management.

He need not lose one hour from his regular business to supervise the gathering and marketing of his crop of pecans. While he makes money at his own business, his orchard unit also makes money for him without sacrificing his time. Tet he is assured? every advantage of co-operative marketing: he knows that Hess Pecans are known from the Atlantic to the Pacific, and that the demand constantly exceeds the supply.

Live at home. Farm Pecans in Georgia.
Expert supervision, at lozver cost than hired help, by our plan. 


\section{Our Plantation is Divided into One-Acre Units.}

Each acre is plotted off on the plan of our property and indicated with an Orchard Unit number.

In each of these mits twenty trees are planted.

The purchaser of an Orchard Unit secures absolute ownership of his land, but the entire plantation is operated as a whole. This plan enables us to clear the land, plant. cultivate and care for the young trees at a fraction of the cost which would be necessary if the units were operated separately.

A $\$ 600$ orchard unit for $\$ 300$.

Possible only under our plan.
Jurlge the economies effected by our plan of co-operative management by the fact that our charge for clearing the acre mit, planting the twenty buclded pecan trees, replacing any that fail to thrive not for one year only, but for five years, and cultivating and caring for your trees for five years is only $\$ 300$, while the average selling price of a good acre unit, with pecan trees four or five years old, is $\$ 600$.

Why can we derelop and sell you a unit worth $\$ 600$ for $\$ 300$ ?

The cost of land, cost of clearing, cost of setting trees and developing a small orchard, is of such magnitude as to be almost prohibitive to any person with a small income. Under the Orchard Unit Plan this cost is reduced owing to the scope of the undertaking. Machinery and stock that would cost an average of $\$ 300$ an acre for a ten-acre orchard, costs only \$20 an acre for a 1,000 acre tract, the cost of an orchardist and the operating expense being in the same proportion. A small orchard managed on a small scale cannot produce pecans within fifty per cent. as cheaply as if that small orchard is a Unit moler large plantation management.

The company gains also by the natural increase in value of the 1.07 .3 acres of fertile pecan growing land which it is planting for itself-and which it holds as pecan orchards monder the same condition which apply on any wnit in the eighteen hundred being sold. All are on an equal basis-co-operative effort in growing and marketing is assured by our enormons interest in the investment made by us in our own units.

\section{"One of the Safest Industries"_-"The Profit is O. K."}

"The Pecan industry is in its infancy. but is being developed very rapid!y" in this immediate section. It is considered one of the safest industries in South Georgia, and the profit is O. K. once you get the trees in good bearing condition." L. J. Cooper, Presiclent First National Bank, Waycross, Georgia. 


\section{\$10 Down Per Unit, \$5 Per Month.}

Each Orchard Unit will cost \$300 muncler the following conditions: Sio down when application is macle for the Orchard Unit, ancl $\$ 5$ per month per Unit until it is paid in full. No interest is charged on deferred payments. Should one prefer to pay cash for one's Orchard Unit, a liscount of ten per cent. will be allowed on the amount of cash paid, and the deed will be delivered at once.

Upon receipt of an application, together with the first payment, an Orchard contract will be prepared and executed and forwarded. Upon the completion of the payments, the deerl will be delivered.

Is the selling price to-day of a perfect four-or five-year-old orchard is $\$ 600$ per acre, baserl on actual sales. one can readily see that since our compensation is only $121 / 2$ per cent. of the profits, we must have unbounded faith in the Lnit System and its application to urchards as well as being absolutely sure that Pecan Orchards in this locality will be highly profitable. We have the required faith and we know the profits are sure or we would not make this offer.

Photographs of the property showing the progress of the trees on the plantation will be forwarded to each min holder each year during the development period, after which time the Company will issue an annual crop report.

Remember that the three hundred dollars cover every expense of cleveloping your mint to bearing age.

The contract of sale plainly states that the purchaser may after the first five years locate his home on his units and look after his own trees, managing his property entirely inclependent of the company. But we believe that our management and our methods of marketing will prove so economical, efficient and satisfactory that the unit owners will always want the company to manage their units and harrest and market their pecans for them.

If any unit holder, who is paying for his mit on the $\$ 5$ per month basis, and shall have nade promptly upon the date called for by contract, eight or more monthly payments in addition to the initial payment of $\$ 10$, should die before his payments of $\$ 300$ per unit are completed, the company will npon proof of death fumish to his estate a deed to his mit or mits and all further payments on the same shall cease. This protects the family or estate of the unit holder who meets his monthly payments promptly, against all possibility of loss due to lis death.

Units full paid in case of death. 


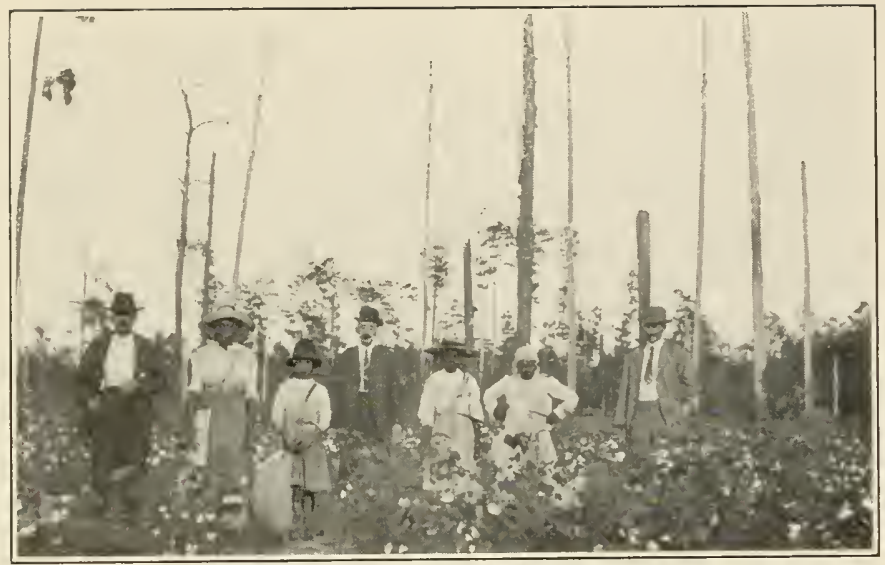

One of our units, ready to be cleared. In this picture the plantation manager is shown at the left; in the center is the Sales Manager of the Pecan Company, Thos. F. Miller, and to the right, M. G. Esbenshade, ]st Vice-President.

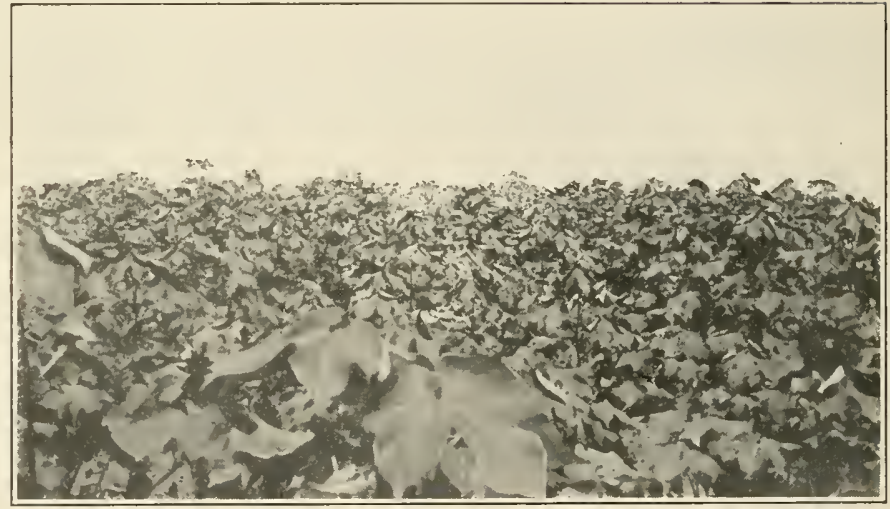

A unit, after stumps have been cleared and cotton planted, ready to plant to pecans.

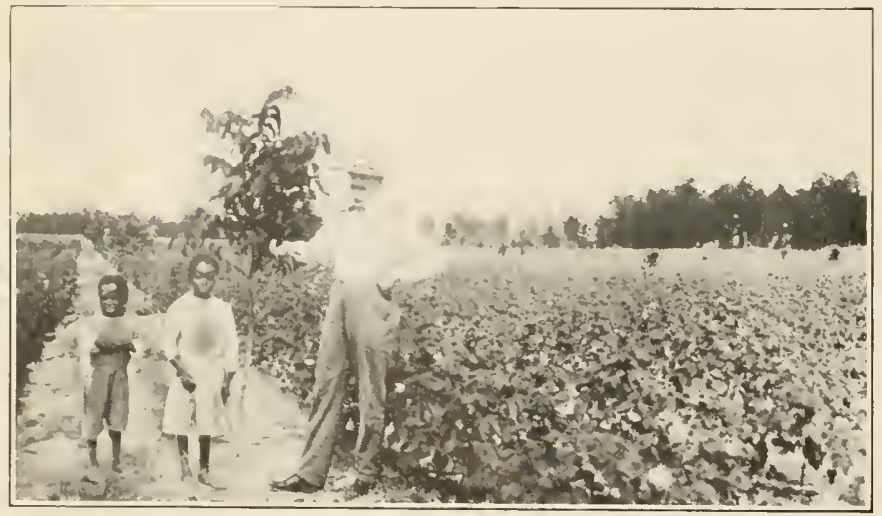

Showing a pecan tree 20 months after planting. The unit holder shown in this picture is George C. Bollinger, Allentown, $\mathrm{Pa}$. 


\section{Each Unit Increases in Value $\$ 100$ Per Year.}

Remember that according to the most authentic information your orchard mit increases in value each year at the rate of $\$$ Ioo per annum; while you make your parments at the rate of only $\$ 65$ the first year and only \$6o each year thereafter.

From the minute the purchaser puts dorn the first $\$$ Io the contract of sale protects him-his is the opportunity to gain from the increase under the value of these units and to reap the profits from the constantly increasing crops of pecans, as soon as the trees begin to bear.

\section{Pecan Orchards Sell at $\$ 1000$ Per Acre.}

As closely as can be figured out a pecan orchard unit which is well established should sell at $\mathrm{S}$ I,ooo or thereabouts. This figure is based upon actual sales of or offers for pecan orchards. most of which were planted with seedlings or varieties which are not so profitable as the finest grade paper shell pecans.

\section{From Waycross, Ga., we hear from A. C. Snedecker:}

"I do not know of any bearing or near-bearing groves for sale here or elsewhere. A four-acre grove thirteen years old, and not especially desirable, was sold at auction a few weeks ago to settle an estate. for $\$ 4.050 .00$."

The Atlanta Constitution (one of the foremost newspapers in America) on January 27. I9IO, published an offer of $\$ 80,000$ for a pecan grore of eighty acres, which the owner. Mrs. Ramsey. declined, as she would not know how to so profitably and safely invest such a large amount elsewhere.

The Americus Times Recorder reports that IIrs. C. IV. Gunnels, of Terrell. Ga., only a few miles from the Kerstone Pecan Company's property, refused a cash offer of $\$ 20.000$ for her grove of eleren or twelre acres, or very nearly \$2,ooo per acre. Most of these trees were seedlings, with but a few budded trees-yet Mrs. Gumnels says she has an assured income from her pecan trees and knows that the trees will prorluce eren larger crops as they grow older.

An Attorney of Albany. Ga.. was authorized to pay $\$ 5.000$ for five acres of Mobile top-worked trees. This offer-Si.ooo an acre-was refused.

\section{An Increase in Value of $\$ 100$ Per Year Per Acre.}

Mr. E. B. Adams. Secretary of the Albany. Ga.. Chamber of Commerce. writes: "Each season the Pecan groves enhance in ralue, it being agreed by eminent Pecan authorities that properly cared for Pecan groves increase $\$_{100}$ an acre in value each year."

This is an investment where your princifa! increases and your income gets larger as the years roil by 
$\$ 1016.00$

Income at

the end

of 10 years.

There is good reason why \$r.ooo an acre is considered so low a selling price by the arerage owner of a bearing pecan orchard that it is only in rare instances that sales are consummated.

A thousand dollars at interest yields at most $\$ 60$ or $\$ 70$ per year, while on conservative figures an orchard unit which cost only $\$ 300$ will yield the seventh year $\$ 160$, the eighth year $\$ 200$, the tenth year $\$ 320$, the fifteenth year $\$ 1000$ and the twentieth year $\$ 1800$.

The table below shows a conservative estimate of the probable yield of an orchard mint, based on fignres which are readily provable.

\section{Average Yield of Orchard Units.}

\begin{tabular}{|c|c|c|c|c|c|c|}
\hline & 4th year & $\begin{array}{l}\text { Per Tree } \\
\text { a few nuts }\end{array}$ & $\begin{array}{c}\text { Average Yield } \\
\text { Per Tree } \\
\text { Nuts at } 40 \mathrm{coc} \text { per lb. }\end{array}$ & $\begin{array}{l}\text { Average Income } \\
\text { Per Tree }\end{array}$ & & $\begin{array}{l}\text { ncome } \\
\text { er Unit }\end{array}$ \\
\hline & 5 th year & 3 to $5 \mathrm{lbs}$. & 4 lbs. & $\$ 1.60$ & $\$$ & 32.00 \\
\hline & 6th year & 5 to $10 \mathrm{lbs}$. & 8 lbs. & 3.20 & & 64.00 \\
\hline & 7 th year & 15 to $25 \mathrm{lbs}$. & $20 \mathrm{lbs}$. & 8.00 & & 160.00 \\
\hline & 8th year & 20 to $35 \mathrm{lbs}$. & 25 lbs. & 10.00 & & 200.00 \\
\hline & 9th year & 24 to $40 \mathrm{lbs}$. & 30 lbs. & 12.00 & & 240.00 \\
\hline $\begin{array}{l}\$ 1016.00 \\
\text { Income at }\end{array}$ & 10th year & 35 to $50 \mathrm{lbs}$. & 40 lbs. & 16.00 & & 320.00 \\
\hline the end & 15th year & 100 to $150 \mathrm{lbs}$. & 125 lbs. & 50.00 & & 1000.00 \\
\hline of 10 years. & 20 th year & 150 to 300 lbs. & $225 \mathrm{lbs}$. & 50.00 & & 1800.00 \\
\hline
\end{tabular}

Possibly the figures in the table astound you. You think there has been some mistake in then-mecause it is almost unbelievable that in less than ten years the aggregate sales from the unit should bring an income as great as your original investment, so that m effect you own your unit and get the subsequent returns without any of your money being invested.

At the end of ten years your $\$ 300$ investment has yielded Your, on the basis of the abore conservative table, \$1,or6.00. This means an arerage of over \$I oo per year on every year since the first payment of $\$ 10$ was made-or orer $\$ 200$ per annum for every one of the five bearing years.

The figures are astounding. Yet there is plenty of evidence that proves they are moderate. Other good authorities indicate as average yield the figures which we state as maximum yield, particularly between the nintl and twentieth years. For instance, to make our table conservative. we have adopted the low figure of one hundred twenty-five pouncls as average yield per tree in the fifteenth year, while the figures generally used for that year are one hundred seventy-five and two hundred pounds per tree.

K. Powell. Cairo, Ga., reports 465 pounds of Pecans from one tree in its twenty-second year. At Monticello, Fla., a seedling pecan twenty-one years old bore 638 pounds of nuts for Mr. O. Lindsay. J. B. MeLean, of Lexington, Mississippi, reports 900 pounds of pecans per annum from one tree, probably forty years old. 


\section{Results Should Far Exceed Our Figures.}

We have indicated a selling price of forty cents per pound, while experience indicates that fifty cents has been the average in the past for the various mixed grades, and less desirable varieties not commanding so large a retail price as the Hess varieties.

We prefer that the investor in one, five or more of our orchard units shall be agreeably surprised at the fact that the yield is greater and the price per pound larger than our table shows. Our interests and those of our investors are identical-selling a unit at our lowsale price benefits us little unless the return which is secured from the gathering and sale of nuts is satisfactory:

\section{Why do we sell Orchard Units?}

We can answer that in a few words:

To raise money for development purposes.

To make it possible for us to meet the demand which already exists for the finest paper shell pecans. We want to plant our 2,873 acre plantation to paper shell pecans as quickly as possible in order that we may share in the profits from selling car loads of pecans instead of tons. This year we had to return the money received with orders for pecans because our supply was exhausted early. Some of our customers hare already asked us to reserve paper shell pecans out of the coming crop to be delivered next holiday season. We have no doubt that even when our entire acreage is in bearing that we will be as short of supplying the rapidly increasing dennand as we are now.

\section{Most Searching Investigation.}

Prospective investors and owners of orchard units are welcome any tinle at the plantation in order that they may see for themselves just what progress has been made and is being made. It is necessary that we shall have undisputed control of the orchard during the first five years-the only period when close cultivation is required-in order that we may make good on our guarantee and turn orer to you a successful orchard at the end of that period. But we shall be glad to have you establish a bungalow or cottage on the ground at any time afterward.

The Country Gentleman tells of one budded tree planted in January, I $\$ 92$, which, including the crop for 1912, yielded 7.797 pounds. One man paid \$150 for one year's crop from this tree. At the end of twenty-one growing seasons this one tree has yielded nearly $\$ 900$.

According to the Southern Cultivator the same tree bore 344 pounds in I9I3.

(Note that the above is based on an average price of joc. per ponnd-while our table is based on $40 \mathrm{C}$ ) 


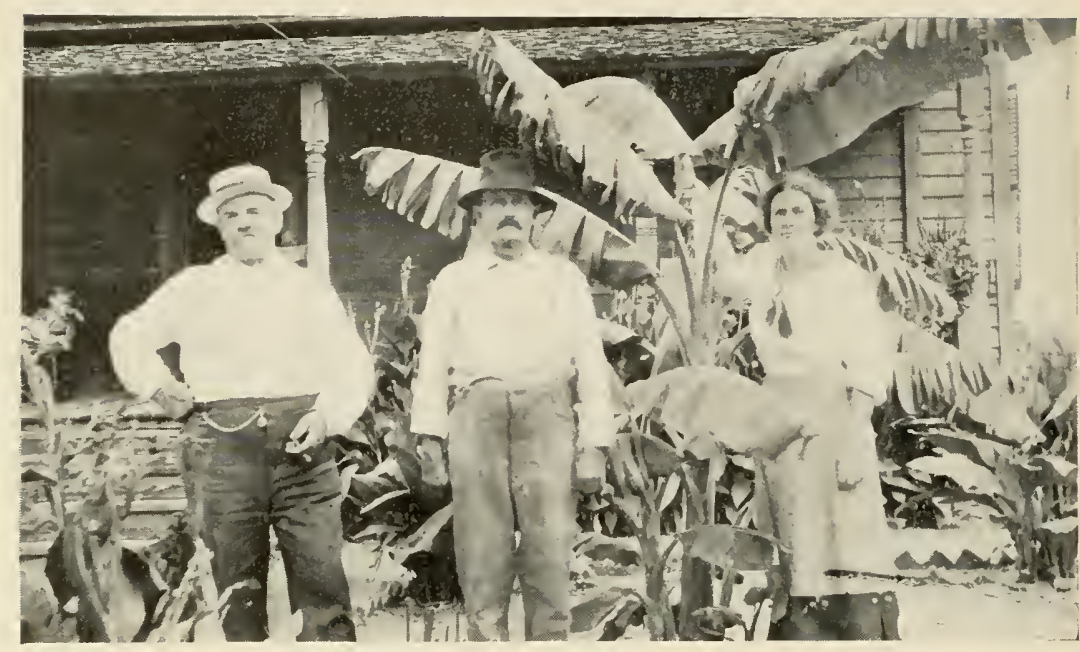

Joseph Seitz, director, visiting Mr. and Mrs. Walker, Plantation residence.

\section{An Ideal Southern Home.}

Practically every thoughtful man looks forward to the time when he may have a home where the winter rigors of the Northern climate shall not sap his vitality. No one need apologize for this longing-or consider it a sign of lack of vigor or backbone.

For the tendency toward establishing homes in the South is not based alone on this desire for an agreeable, equable climate. It is founded on sound economic principles.

\section{Where}

Winter does not consume what the Summer produces.

Fishing and hunting aplenty.
In the North, the winter consumes the food which the summer produces. In the fertile sections of Southern Georgia a succession of crops properly planned makes the whole year productive. You can accomplish more in one year than in several years in the North. Vegetation is so rapid that in two years a home is surrounded by a growth of trees, flowers, shrubbery and growing crops which it would require five years to develop in a cooler, Northern clime.

While the people of many Northern cities are chilled to the marrow in Winter, and swelter under the heat and humidity of Summer, the Government statistics show a surprisingly slight variation between Vinter and Summer in Southern Georgia. Here there is no enervating humidity compared to that found in the Northern and Central Atlantic States.

Here is the ideal home- "where the sun shines bright, and the meadow's in bloom"-where good fishing and hunting aboundwhere the call of the "Bob White" is heard from September to

\section{Not a Crop Missed for 15 to 20 Years.}

U. S. Bulletin, page 3I9, in speaking of the Mantura Pecan, says:

"Up to 1907 it has not missed a crop for I5 to 20 years, the crops for the previous ten years having averaged Ioo pounds, and for several years i 50 to 275 pounds." 
March-where the outdoor life is the natural, healthful life the year round.

Here with the fine southern town of Albany only a short distance away, with fine roads extending roundabout in all direction, you may live on a typical plantation.

While Nature, soil and sun combine to produce profitable crops on the Pecan trees which have been turned over to you a bearing orchard, you may fish, boat or swim on the beautiful Lake Marcelia-a twenty-five acre lake right on our plantation. The water for this lake originates in Crystal Springs, the banks of the lake are devoid of swamps and are surrounded by beautiful groves of live oak, covered with the beautiful Spanish Moss-an air plant which like other parasitic growths, cannot grow on the pecan tree.

We expect eventually to erect a club house or hotel on the banks of this lake where unit owners may be accommodated should they wish to spend their vacation here enjoying the delightful climate of Southern Georgia during the cold winter season of the north, enjoying hunting and fishing.

Then you live amid such surroundings-you really live.

The country all about is so attractive that many a man in the North would be glad to pay $\$ 300$ for an acre on which to build a southern home. If he planted on that acre only enough pecan trees to yield an average income of $\$ 18$ per year, he would have six per cent. interest from his money. One tree would yield more than \$rg per year, on an average, from the fifth to the twentieth year. Why be satisfied with a single tree when there is room for twenty trees and a small bungalow on vour acre?

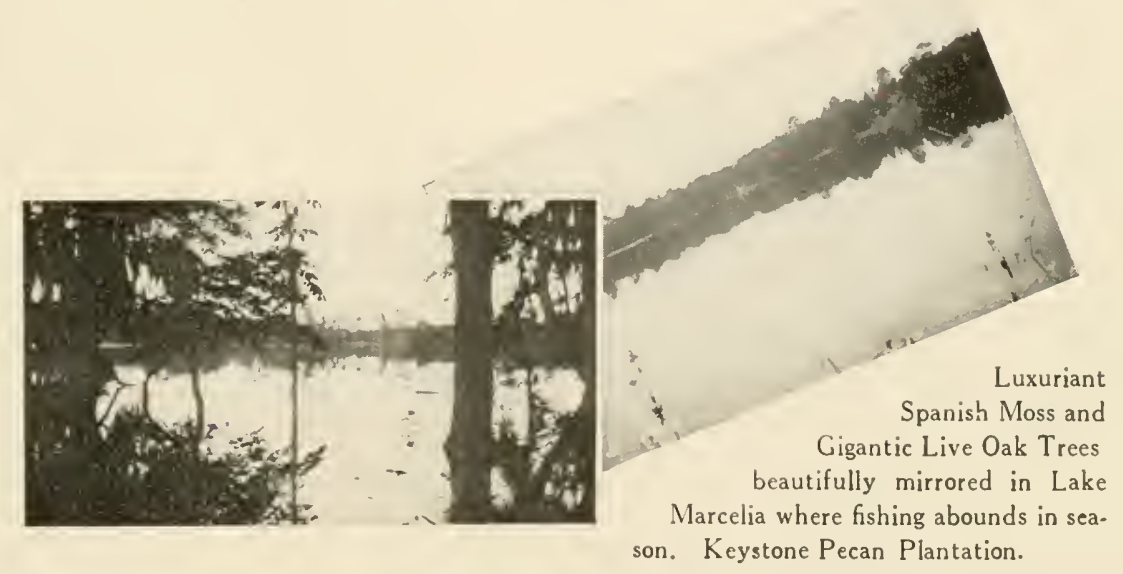

U. S. Bulletin of Department of Agriculture, 1909, tells on page 384 of one tree which bore a crop of 450 pounds, and on page 385 of another which bore a crop of 400 pounds.

Fine tozen nearby.

A Southern home-site. 


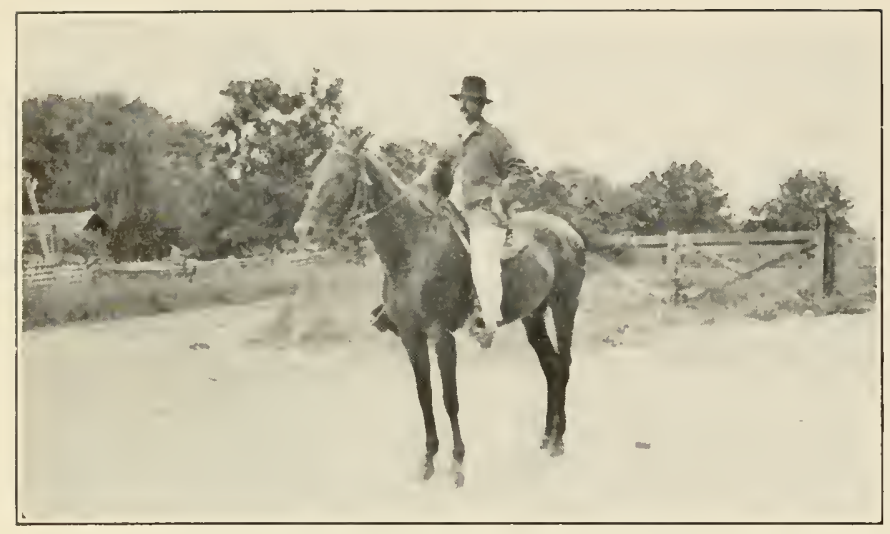

The manager of the Keystone Pecan Company Plantation inspecting the progress of the orchards.

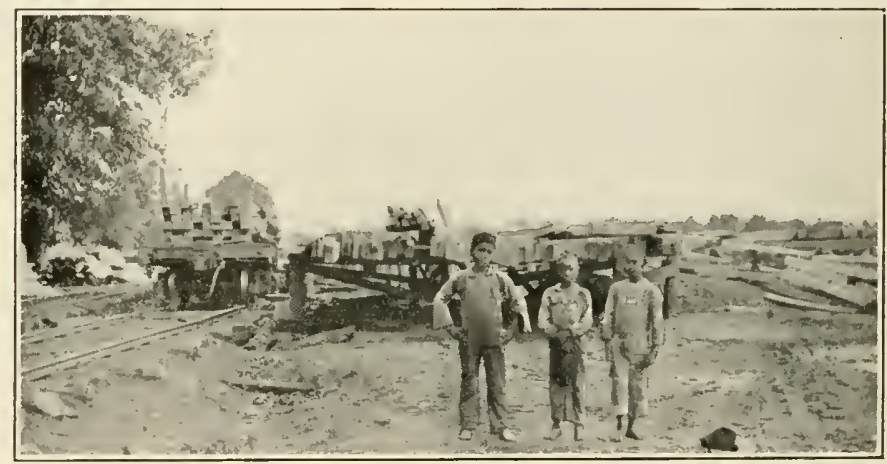

The freight station on our Plantation which enables us to ship promptly and economically over the Georgia Central Railroad.

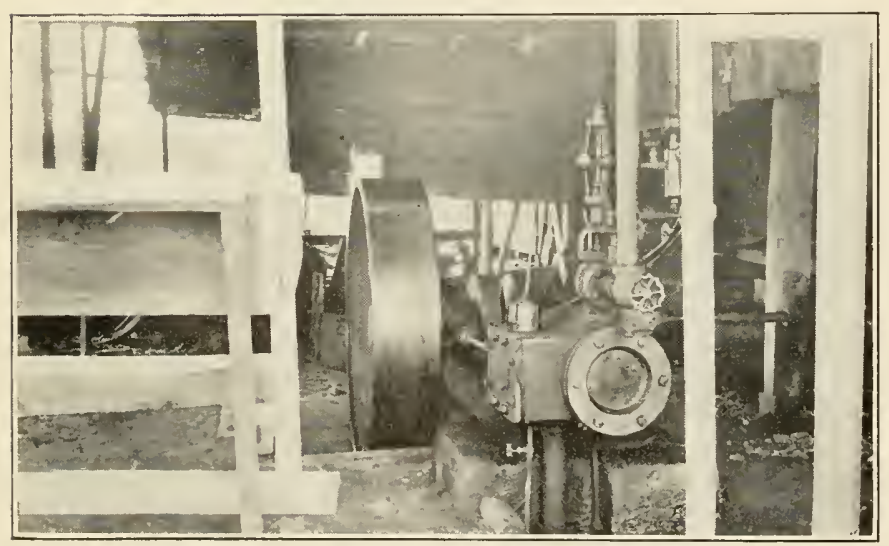

An engine on the Keystone Pecan Company Plantation. Used in ginning cotton and grinding corn. 


\section{Investigate the Company-and its Officers.}

Because the most conservative statement of yield from our pecan units sounds too good to be true, we have found that it was necessary to urge prospects to investigate erery phase of the company.

For this reason, the men who have invested most largely are always the men most capable of getting at the real facts-and acting on their own knowledge, lawyers, bank officials, doctors, dentists, ministers, school-teachers, business-managers, merchants, bookkeepers and others of the most intelligent classes are beconing owners of one, five, ten and fifty unit orchards because their inrestigation has shown:

First. That the Company is financially strong-\$ 50,000 corporation, which received its charter in I9 I from the Superior Court of Georgia. Subsequent to the incorporation, the Company pur-

Why your investment is secure chased what its officers believed to be the finest plantation in Calhoun County for the growth and development of Paper Shell Pecans. The plantation consists of 2,873 acres of land, which is being gradually developed and planted in Pecan Orchards. From the date of the purchase the Company has expended large sums of money annually upon the development of the property, and notwithstanding this fact, the entire plantation is subject to a lien of only Twentyfive Thousand Dollars $\left(\$_{25}, 000\right)$, and to provide for this charge a sufficient amount is set aside from the sale of each Orchard to discharge the lien upon the land sold. This fund is in the hands of a special Trustee appointed for that purpose. whose duty it is from time to time to secure releases of lien, which is done when the fund is sufficiently large to meet the requirements of the lien creditor. The lien clarged on the entire property is less than Ten Dollars (\$ro.0o) per acre, but the Company, to assime more speedily releases, set aside more than twice the amount of the charge per acre so that under this plan the entire lien is disclarged before one-lualf of the property is sold and convered. This plan was specially devised for the protection of Unit buyers, and we know of 110 Company that has devised a safer plan. It is the prodnction of the nost careful consideration given in the interest of the Unit burer. It is the application of the "Safety First" principle.

Second. That the orchards are under capable supervision. The active officers of the Company were close students of pecan growing for years previous to ror I.

"Pecan growing is subject to none of the perils of stock or cattle raising. such as hoof and mouth disease. The pecan is of the hickory family. It defies drought and frost. Tet Pecan meat is growing in popularity; while the production of animal flesh fails to keep pace with the population." 
Realizing the fact that the making of profits depend in part on the skill of the orchardist, the company employed as Superintendent of Orchards, an educated, practical horticulturist, having a large pecan grove of his own, where he earned a reputation as an orchardist that secured him highest recommendation of well known authorities. The fact that such a man accepted the position with the Keystone Pecan Company is a tribute to the possibilities of this plantation, for he is too ardent a lover of pecans and regards his reputation too highly to engage in an orchard proposition where there is the least element of chance.

For a plantation manager they chose a man who knows every inch of the property, having been on it over twenty years.

Third. That the Company has the character of soil, the kind of budded trees, and the shipping facilities needed to fill the demand for better grade pecans which come from all over America and abroad. The immediate district in which our plantation is located is the natural home of the pecan. No place in the known world is so well adapted to the growth and perfect development of the pecan as this immediate district. The soil and the climate is peculiarly adapted to the rapid growth of the tree and to producing and maturing the nut crop to the very highest degree of perfection. (See letters from food specialists who purchased Hess Pecans-bottom of pages Io and 23.)

Fourth. That this Company had recently proved by actual sales, made from advertising, that these finer grade pecans conld be sold to the retail trade at prices fifty per cent. higher than most pecan growers secure for their finest product-because of superior quality of the nuts and superior methods of merchandising. (Note that the table on page 32 is based on an average selling price per pound of $40 \mathrm{Oc}$, while other authorities use fifty cents per pound in all their calculations, despite the fact that higher prices have prevailed on Hess Pecans.)

Fifth. The Company has demonstrated also that its management is capable and efficient. Every one is interested heartily in the success of the orchards. All are men of unquestioned honor and ability; as inquiry in their home cities will prove. They are, as the following pages show, men old enough and experienced enough to capably manage the business, yet young enough to retain their business capacity and vigor for many years to come.

From the cashier of The Bank of Leary, Ga., H. S. Carson, we hear: "After making investigation and spending some time on your nice grove near here, I am very optimistic over the same. I know of no investment that looks so good at present, and my recent trip confirms my belief that the soil and climate is particularly adapted to the growth of Pecans." 


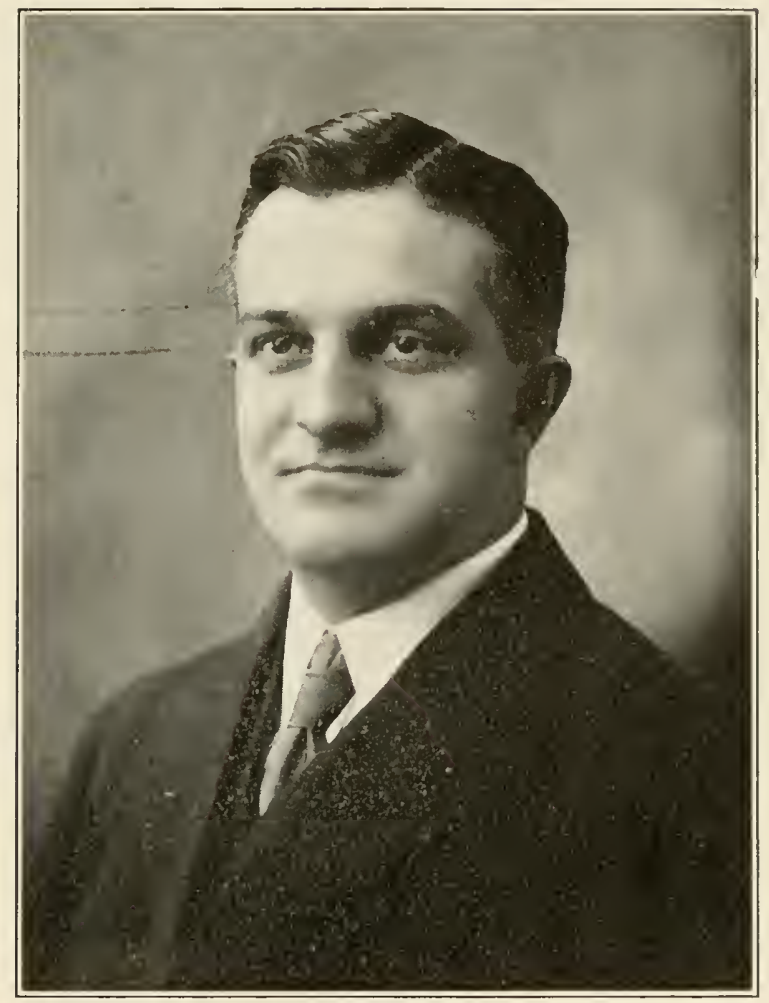

ELAM G. HESS.

Elam G. Hess, President of the Keystone Pecan Co., is a resident of Manheim, Lancaster Co., $\mathrm{Pa}$., and is well and favorably known, not only throughout Lancaster County, but in many parts of America. Mr. Hess, who is thirty-eight years of age, worked on his father's farm in Lancaster County, until he was eighteen years of age. He taught public school for five years, prepared for college at Perkiomen Seminary, graduating in 1902, and in 1906 graduated from Gettysburg College. He had acted as a traveling salesman during his summer vacations for Underwood \& Underwoorl, New York, and had built such a reputation for fair dealing among the best class of trade that he was appointed field manager, along with Mr. Thomas F. Miller. After serving in this capacity for two years, he was sent to England to represent the same company.

In his travels he was impressed with the opportunities which existed for finer grade pecan nuts, and began to make an exhaustive study of their production and their selling possibilities-one result of which has been the formation of the Keystone Pecan Company.

Mr. Hess derotes his entire time to the success of the Company, and is an acknowledged authority on pecan nuts, their growth and their marketing.

Reference: Keystone National Bank, Manheim, Pa.

\section{"The Shell is Thin and Full of Meat."}

From a purchaser of Hess Paper Shell Pecans: "I think the flaror beyond any nuts we have ever had, the shell is thin and full of meat." A. R. S.. Belmont, Mass. 


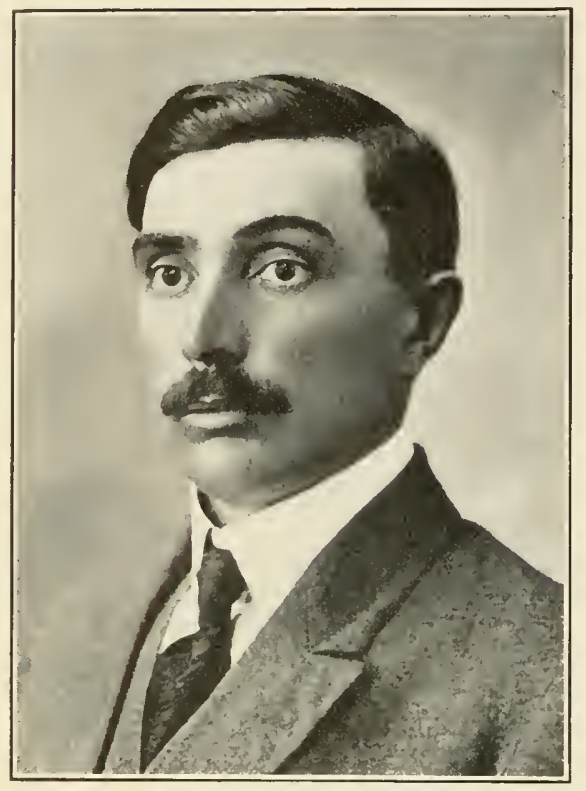

M. G. ESBENSHADE.

\section{G. Esbenshade,}

\section{First Vice-President of the Keystone Pecan Co.}

lives on the farm in Lancaster $C o$. on which he spent his boyhood days. (R. F. D. No. 3.) He is noted throughout the county and beyond as a successful grower of tobacco and potatoes. He is to years of age, a graduate of Lancaster Business College, a director of the Farmers Association of Lancaster County.

In his extensive travels throughout the United States he has visited nearly every State. Mr. Esbenshade has received valuable first hand information on the growing and marketing of large food crops-especiaily nuts. In IS95 he travelled widely in Florida, paying special attention to orange and citrus fruit groves and pineapple fields, and in $\mathrm{I} S \mathrm{~g}$ the worked with the large growers of wheat in Dakota and California and in the apple orchards of Colorado. In igo5 he made another trip south, studving the groves along the Gulf Coast in which wild and seedling pecans were raised. since which time he has made several trips througlout the south with special reference to Paper Shell Pecans.

Reference: The Northern Trust and Savings Bank of Lancaster. Pa.

\section{Enos H. Hess,}

Second Vice-President of the Keystone Pecan Co.

lives on the farm on which he was rearedR. F. D. No. 3. Lancaster, Pa. $\mathrm{He}$ is 45 years of age. He is noted as a truck farmer, selling his own products to Lancaster City consumers at famous Lancaster Markets, which he attends twice a week.

Formerly a director of the Ideal Cocoa Company, Lititz, $\mathrm{Pa}$.

Reference: Farmers Trust Co., Lancaster. Pa.

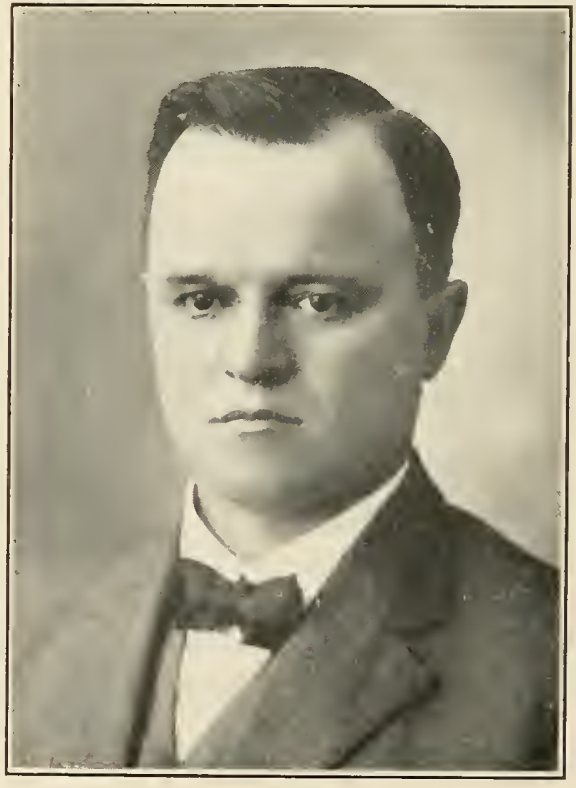

ENOS H. HESS. 


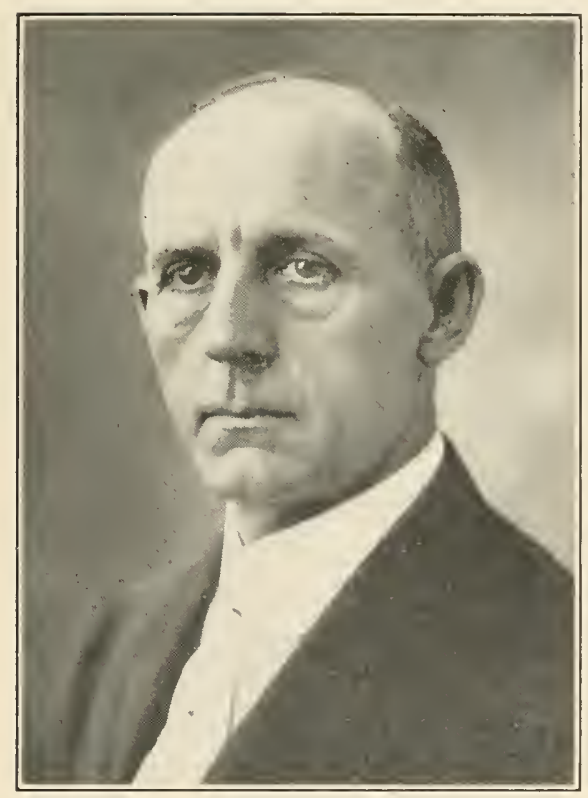

\section{F. G. Young,}

Secretary and Treasurer of the Keystone Pecan Co.

is a dealer in real estate and real estate investment securities with offices in the Woolworth Building, Lancaster, Pa. After thoroughly investigating the possibilities of nut culture, and especially pecan nut culture in southwest Georgia, and the constantly increasing demand for nut meat, became connected with the Keystone Pecan Company.

A native of Indiana, where he engaged successfully with the Blickensderfer $1 \mathrm{fg}$. Co. with offices in Indianapolis, and subsequently at Cleveland, Ohio.

He has resided in Lancaster for nearly ten years, and known as a highly successful salesman.

Reference: Lnion Trust Co, Lancaster, Pa.

F. G. YOUNG

\section{Joseph Seitz,}

Director of the Keystone Pecan Co.

is a native of Lancaster Co., residing at Mountville, Pa., formerly a farmer, now a dealer in leaf tobacco.

Reference: Mountrille National Bank.

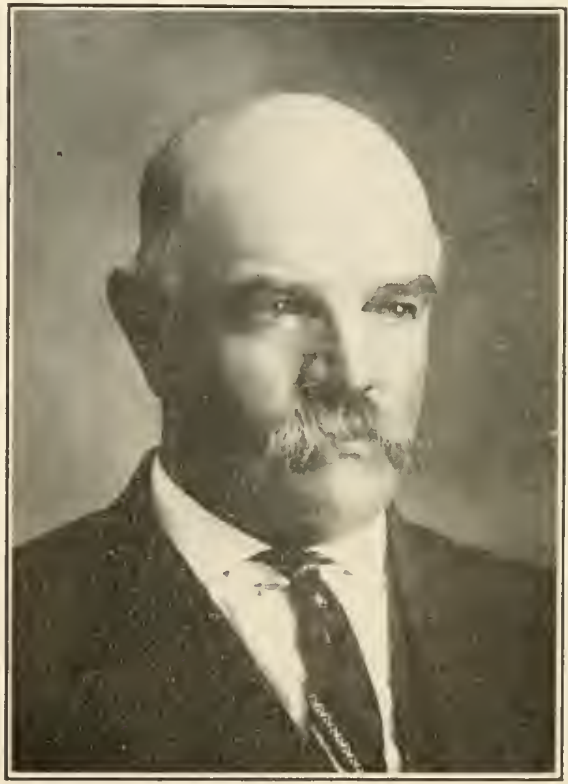

JOSEPH SEITZ. 


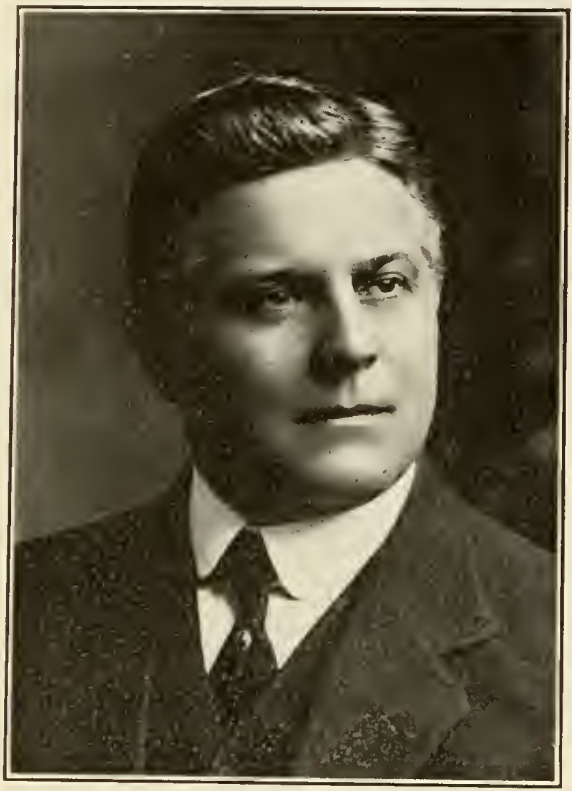

\section{G. Hess,}

Director of the Keystone Pecan Co.

is 5o years of age. He resides at Manheim, Pa., and was for about twenty years cashier of the Keystone National Bank of Manheim.

He is now Treasurer and General Manager of the Manheim Mfg. and Belting Co.-a highly successful business.

Reference: Lancaster Trust Co.

M. G. HESS.

\section{Willis G. Kendig,}

Director of the Keystone Pecan Co.

is one of the most noted corporation lawyers of Lancaster. He is widlely known as a lawyer of keen discrimination regarding commercial enterprises, and the fact that he and so many associates from the richest agricultural county in the United States place their money in this Georgia pecan orcharl is evidence of its worth. Mr. Kendig is 40 years of age; the son of a doctor of Salunga, P’., who also enjoyed a most excellent reputation in his field.

References: Fulton National Bank.

\section{Joseph A. Phillips}

Director of the Keystone Pecan Co

is the Mayor of Mercersburg, Franklin County, Pa., which position he has held for almost five years. Age 55. He has been a seed merchant for twenty-seven years, doing a broad business, for which the first twenty-three years of his life-spent on the farm-has well fitted him.

Reference: First National Bank of Mercersburg.

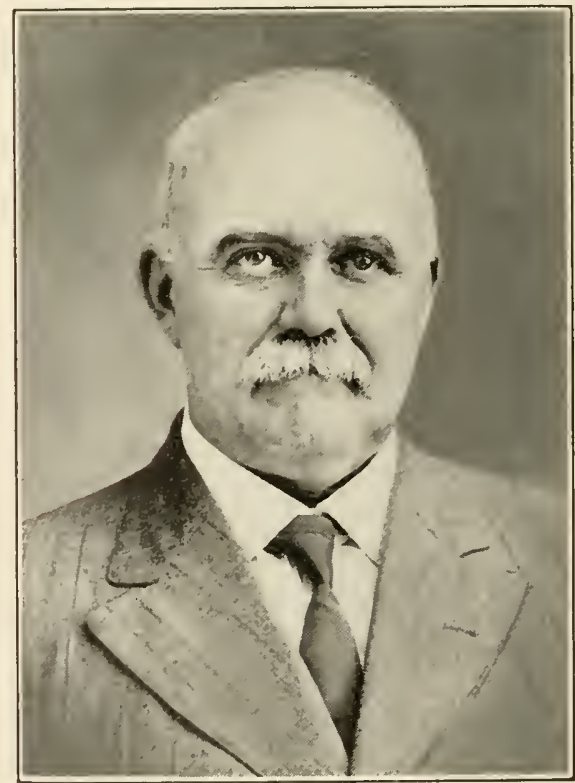

JOSEPH A. PHILLIPS 


\section{B. L. Johnson,}

\section{Director of the Keystone Pecan Co.}

resides in Allentown, $\mathrm{Pa}$., and is Sales Manager for that district-embracing important counties in Pennsylvania and New Jersey-for the Burroughs Adding Machine Company, a $\$ 5.500,000$ corporation, which is known all over the world. Mr. Johnson is known throughout the Allentown district as a self-made man, who has at an early age held positions of trust and responsibility because of his earnest and efficient work and his remarkable business judgment.

Reference: Penn Counties Trust Co.

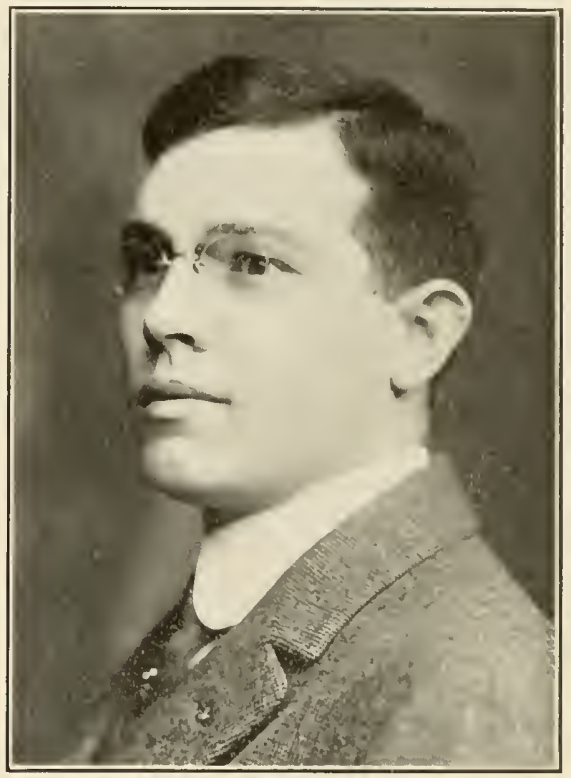

B L. JOHNSON

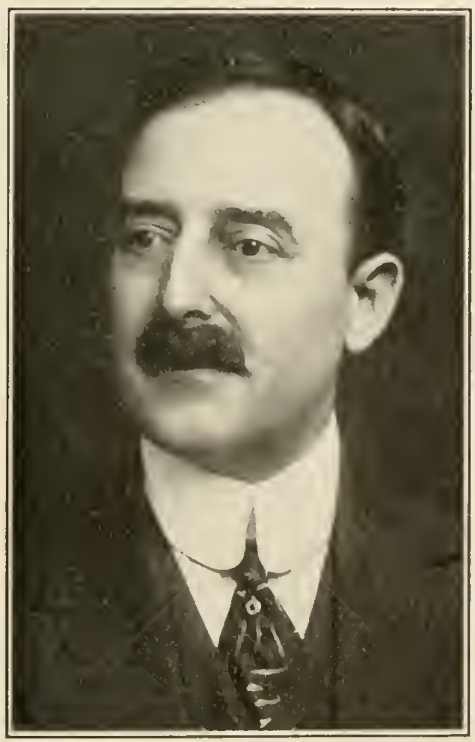

Thos. F. Miller,

Sales Manager of the Keystone Pecan Co.

is 4 I years of age. A graduate of State Normal School and also of Lebanon Valley College, and taught public school three years. He has had long, successful experience in selling, and was sixteen years in the employ of Underwood \& Underwood, and was associated with Elam G. Hess, President of the Company, as Field Nanager, appointing and drilling hundreds of sticcessful salesmen for their Travel System. He resides in Allentown, Pa., and is favorably known as a man of high ability and good reputation. Note his letter herewith.

Reference: Merchants National Bank. 
Thos. F. Miller,

950 Jackson St.. Allentown, Pa.

Allentown, Pa., May 24, I915.

Elam G. Hess, Pres. Keystone Pecan Co., Manhein, Pa.

Dear Mr. Hess:

Your communication asking me to write a letter stating "How I became interested in Paper Shell Pecan culture and in the Keystone Pecan Conpany" received.

$\lambda I y$ interest in this new industry and my ambition to some day own a pecan orchard dates back before the Keystone Pecan Co. was in existence. My study of this improved nut. its food value. the whole world to supply, its advantages over other tree crops, in harvesting. packing, shipping, not perishable, besides the long life of the trees and the small expense of up-keep after the fifth year and the wonderful yield satisfied me that it was the safest and most profitabie industry I know.

When you conceived and formed the Keystone Pecan Company with its co-operative plan I saw my opportunity and invested and purchased Lnits. Having been in business with you for so many years and knowing your capacity to plan big business and your ability to carry your plans to perfection, also the other members of the company being known as clean, honest and progressive business men gave me explicit confidence.

When you wanted me to become sales manger I decisled to visit the plantation. In Octiber, I9I3. in company with some of my friends. I made my first visit. We were delighted beyond expression with everything. Competent management which seemed to be working out a perfect system. The trees and tons of pecans and acres of rigorous thrifty young trees was evidence enongh to convince anyone that this is the soil and climate where pecans do their best. Iy friends with me incested, and to my knoaledge ciery one who has aisited the plantation since has incested as much as their circumstance atould permit. Some have assumed heavy obligation so that they and their family would be provided with a permanent and increasing income through life and possibly a century or more thereafter. We feel that we must work hard now to support our units for a short time, but later they will work for us and support us. The enthusiasm of those who have been on the plantation and investigated and kncw the men back of it, and who have invested their own money, is the strongest kind of evidence of the merit of the proposition.

Yours sincerely,

THOS. F. MIILLER.

From Mir. George C. Bollunger, an orchard unit purchaser.

The most interesting trip of my life was my visit to the plantation of the Keystone Pacan Company. We remained over night at the hotel in Albany, and the next morning went to the plantation. We first came to one of the plantation corner-stones, and as we travelled on probably half a mile farther, we came to the beatiful lake on the plantation, still farther on we came to the cotton gin and then to the plantation home. occupied at the present time by Mr. Walker, the local manager.

I then began to realize as never before the immensity and opportunities for the proposition. and as we began our journey through the nursery, filled with thrifty young trees, then through the old orchard of stately trees literally bearing down with nuts, then through acres and acres of the finest cotton, then fields of corn, then open land not pianted at present, then more cotton and still more corn, and probably a strip or stretch of woodland and then through the young orchards, planted in IOI3 and I9I4, and still more fields of cotton and corn, unt il we had covered a stretch of land over four miles long and about two and one-half miles wide. I remarked then that surely this would eventually be the finest orchard of any kind in the United States, and I felt that I would like to make my home there.

One of the things that interested me greatly was the black, rich, loamy soil that seemed to be identically the same over the entire plantation. I found the plantation to consist of beautiful slightly rolling land, with no trace of the swampy variety found in some parts of the Gulf States. I

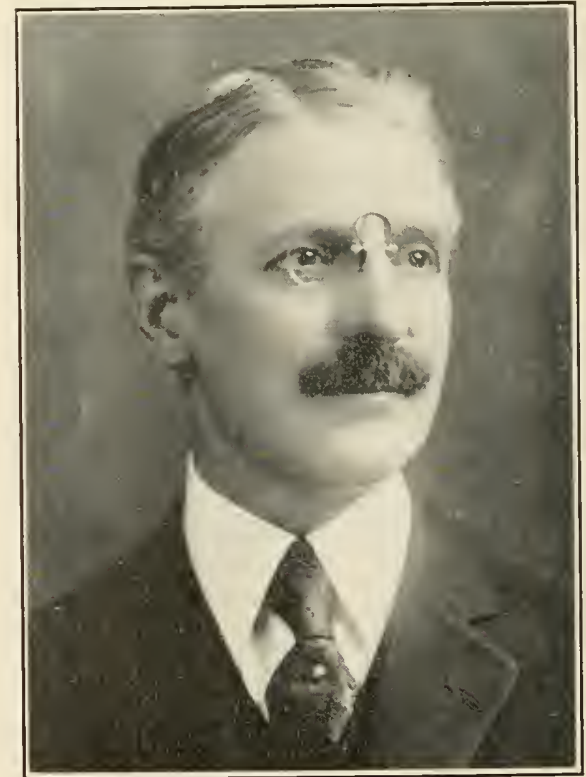

GEO. C. BOLLINGER 
also found everything to conform strictly as it has been represented to me. As an investor, I have carefully considered the two most important questions from an investor's standpoint. First, Is it a save investment? Second, ls it a paying investment?

In answer to the first question, will say from what I saw and learned on the plantation, I consider it gilt edge. Real estate, which is the basis of this proposition, is the safest kind of an investment. It seems to me as this industry advances, that bare land will be so in demand in this pecan section that it will command a very high price. Ny investment is secured by the company who has invested their money and must depend on making a success of my units, as it is co-operative, and the profits to all depend in growing large quantities of pecans.

In answer to the second question: "Is it a paying investment?" This is very easy to answer, as growers have kept accurate records of their trees from year to year, which furnish not estimates but facts on which to base calculations. I saw a sixteen-year-old tree that bore over two hundred pounds in 1914. The record of this tree shows that it bore not less than one hundred and eighty pounds per year during the past five years. Records show six-year-old trees bearing as high as thirty-seven and a half pounds. In nearly every instance the records showed a higher yield than the general estimates which were given in the literature.

I have also had the experience of selling the "Hess Pecans" right in my own community. My firm, J. A. Eberts \& Co., having handled a large part of the IgIt crop. WV had a surprisingly large sale considering the fact that paper shell pecans had never before been seen or heard of anywhere in this section. The No. I Hess Pecan retailed at \$1.0o for a twelve-ounce box, or at the rate of \$1.33 per pound.

I can conscientiously say, after having visited the plantation and having become thoroughly familiar with all phases of the proposition-having become acquainted with the men who compose the Company, and above all the honesty and integrity of the management. I consider it the safest and most profitable investment that has ever come to my notice, and conscientiously recommend the investment to any one, earnestly believing it is an opportminty that is rarely met more than once in an entire lifetime.

GEO. C. BOLLINGER.

With J. A. Emerts \& Company.

Allentown. Pa., May 31, I915.

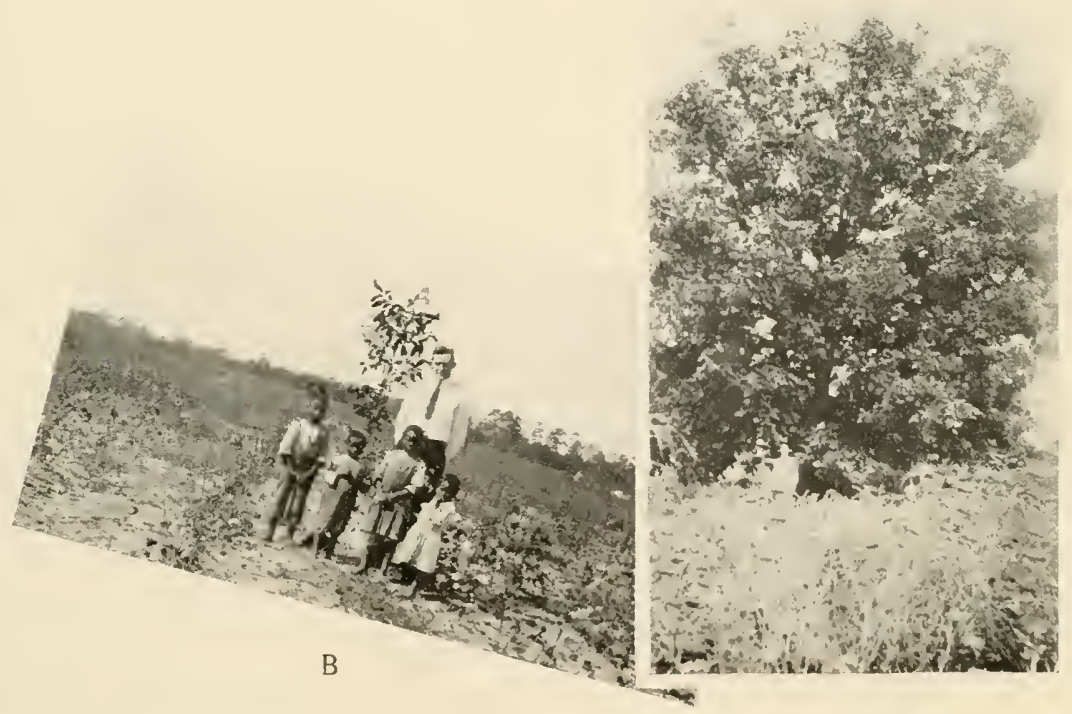

A

A-George C. Bollinger, of Allentown, Pa., standing by a tree on our plantation which bore 225 lbs. of pecans last season. B-Lloyd W. Hoagland, of Sommerville, N. J., a well known automobile salesman, A graduate of the University of Pennsylvania, another man who came, saw and bought.

\section{Not An Imperfect Nut in the Lot.}

"The pecan nuts purchased from you were the finest we have ever used, and were in every way satisfactory, as there was not one imperfect one in the lot." M. E. McD., Roselle, N. J. 


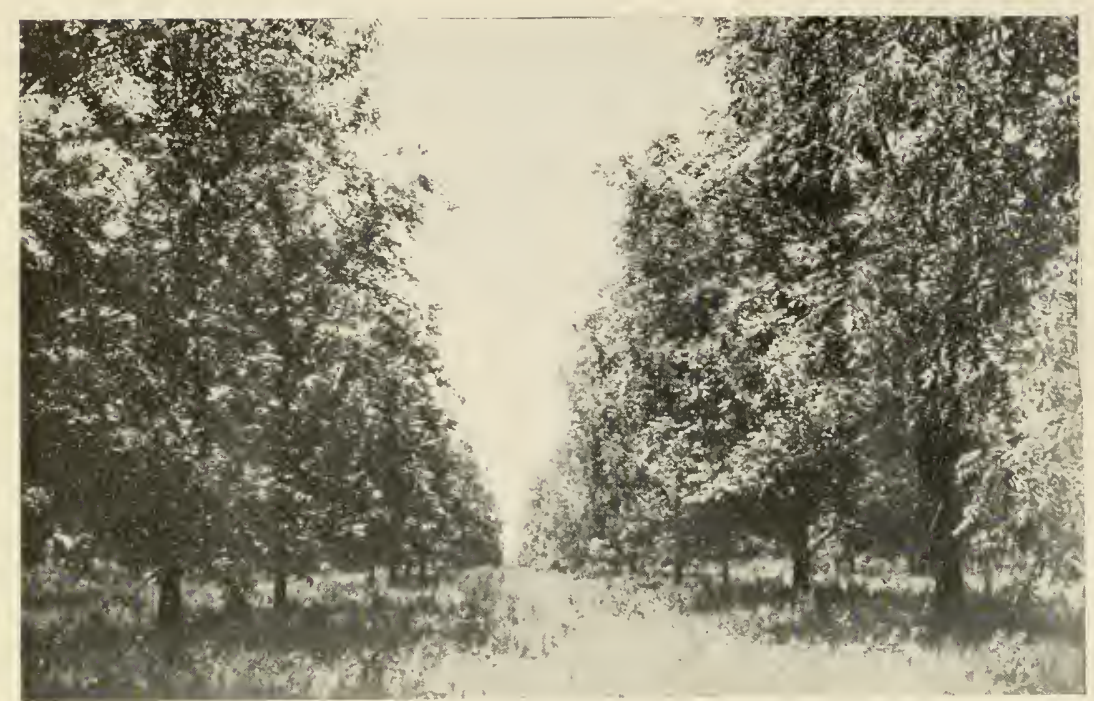

Pecan Nut Orchard on our plantation in Calhoun Co. Ceorgia. 1914 crop sold from Maine to California.

\section{No Investment Could be Safer.}

Think it over. Let your own judgment decide. Ask yourself these questions in regard to any investment you have under consideration.

What is the security back of my investment? In the Keystone Pecan Co. there is an acre of land which becomes yours on the payment of $\$ 300$. Remember this-you own the acre of land itself.

Land is the safeguard of the safe investments. Land cannot burn up, cannot be stolen: land cannot be wiped out by panics. The biggest trusts base their bond issues and their mortgages on land-yet the manufacturing plants which are built on that land may, due to panic, fail to produce enough to pay interest on the bonds or mortgages. Even the largest industrial companies have suspended or decreased dividends since the European War startedyet nature continues to provide foodstuffs and man still needs to eat them.

Productive land is the best of land investments. Tree crops are the profitable crops, which make land most productive. Note that the Country Gentleman tells of single trees making more human food than a whole acre of Kentucky blue grass.

\section{Orders 12 Pounds-Wants Prices on Larger Quantities.}

"Have also received the box of pecans, which I find satisfactory as illustrated in every respect. Kindly send me a I2 pound carton of same variety. Also kindly give me your prices on !arger quantities." A. S. B., Portland, Oregon. 
The pecan is the surest of profitable crops-because after the first five years, during which we assume all the risks, the pecan requires practically no attention. Gathering the nuts and selling them represents the bulk of the effort required after the first five years.

You cannot be deceived on this score-because we bind ourselves by contract to do this work for $12 \mathrm{I} / 2$ per cent. of the profit. Would we deceive ourselves - could we afford to take any chances if we did not know that the pecan is as hardy a tree as the hickory or oak, free from the dangers of frost and blight, and a surer profit payer than any other crop of any sort?

We could not give such a guarantee on a fruit tree-for every farmer knows that apples and peaches are subject to many perils of frost, storm, blight-borer, and of loss in shipment. Pecans are hardier than hickory nuts, they cannot be shook off the tree till ripe. Citrus fruits-like oranges and grape fruit-are liable to frost, and spoil so quickly that it is impossibie to hold them long before marketing. Paper Shell Pecans can be held a year without losing their delicious flavor and nutritive value.

There can be no glut of fine pecans-because they can be raised only in limited territory, they have the whole world for a market and the whole year for a selling season. As the famous Luther Burbank well says (see page 13 ): "We have now one pecan where we ought to have a million to create a market."

An assurd increasing market for perfected pecans, at an excellent profit, is back of every dollar you invest here.

\section{Who Should Invest in Pecan Orchards?}

To provide an income for later years, "He must," says the American Fruit and Nut Journal, "look to a business that will increase in value and returns. The improved Pecan orchard fulfills all these requirements. It is safe, pays little at the beginning, but increases its income gradually, and when ten or fifteen years old will yield ten times more than the same money would in almost any other business."

"On many articles of food, from meats to fruits, the cost of loss in transportation eats the heart out of the profits. Pecans require no refrigeration; kept in any cool, dry place without loss or deterioration, can be shipped all over the world-fear no competition from abroad for they are grown only in the most limited districts in America."

The young man. 


\section{Who Should Invest in Keystone Pecan Orchards?}

The man of middle-age and abov'e.

\section{Husbands} and parents.

\section{Business and professional people-all men or women with foresight.}

(Continued from page 47.)

To provide now while his earning power is at its greatest, for those years when his energy begins to ebb-let him plant his money where it grows. As J. B. Wright said before the American Pomological Society: "Plant a pecan grove, and when you are old, it will support you. $* * *$ It will lighten your burdens while here, and when you are gone your children and your children's children will rise up and call you blessed."

To provide an annuity for their wives and families. which will exceed in annual return any equal investment for the purpose and which will yield a growing income each year. No father wants to look forward and see the home broken up for lack of income, the wife deprived of comfort and the children deprived of educationbecause he put off till the morrow which never comes, this investment for their protection.

Business and professional incomes vary greatly. There should be some provision for the years of reduced earning power-when conditions beyond your control cut to a mere fraction the satisfactory income of last year. Because pecan orchards have their foundation in land, because Nature yields her crops abundantly despite wars and panics, because the demand for Hess Pecans, which we have proved within. was not effected by the hard times in the winter of I9I -'i 5 , you know that here is a dependable source of income. The period of uncertainty on pecans is the first five years -when we assume the risk!

\section{"For want and age save while you may, \\ No morning sun shines the whole day,"}

says Ben Franklin. Are you saving for the "rainy day?" Ask yourself that question-and insist on a fair answer.

Accept no excuses-excuses will not provide for you and your loved ones in years to come.

Don't say, "I'll begin to invest when I get a larger income." If your income were reduced a tenth to-day-you would manage to live on the balance. Put that tenth now where it will protect you against "the slings and arrows of outrageous fortune."

Orchard Unit Applications are Enclosed for Your Convenience.

Select which you may desire, full cash payment or deferred payments.

\section{KEYSTONE PECAN COMPANY}

\section{Southern Office on Our Plantation}

Calhoun Co., Georgia.

\section{Northern Office}

Woolworth Building, Lancaster, $\mathrm{Pa}$

\section{President's Office}

Manheim, Lancaster Co., Pa.

Please mail all applications and checks to Keystone Pecan Co., Manheim, Lancaster Co., Pa. 


\section{DEFERRED PAYMENT \\ Pecan Orchard Unit Application}

To ELAM G. HESS, President

KEYSTONE PECAN CO.

MANHEIM, PA.

I hereby apply for How many Orchard Units of the Keystone Pecan Company, situate in Calhoun County, Georgia, and I agree to pay for the same at the rate of Three Hundred Dollars (\$300) per Unit, as follows:

(\$10 for each unit desired)

Dollars accompanying this application, the receipt whereof is hereby acknowledged by the Company, and

(\$S per month per unit)

Dollars per month, payable on the first of each and every month until the entire purchase price is paid, at which time I am to receive a Warranty Deed in fee simple for the Units purchased. It is understood that each Unit shall be planted to twenty (20) paper shell pecan trees of the standard varieties. If my payments are made promptly on the first day of each month, the Company hereby agrees that my Units shall become full paid in case of my death, as fully explained on the reberse side of this application.

Application accepted for the company by

Signed

Street and No.

City and State

\section{CASH PAYMENT-10\% Discount \\ Pecan Orchard Unit Application}

To ELAM G. HESS, President

KEYSTONE PECAN CO.

MANHEIM, PA.

I hereby apply for How many

Orchard Units of the Keystone Pecan Company, situate in Calhoun County, Georgia, and I agree to pay for the same at the rate of Three Hundred Dollars $(\$ 300)$ per Unit, on the following understanding:

That accompanying this application I shall make remittance of $\$ 270$ per Unit and shall receive full paid receipt and deed for Unit, the Company allowing $10 \%$ for cash with application.

Application accepted for the company by

Signed

Street and No.

City and State 


\section{Units Full Paid in Case of Death.}

II If any unit-holder, who is paying for his unit on the $\$ 5$ per month basis and shall have made promptly upon the date called for by contract, eight or more monthly payments in addition to the initial payment of $\$ 10$, should die before his payments of $\$ 300$ per unit are completed, the company will upon proof of death furnish to his estate a deed to his unit or units and all further payments on the same shall cease. This protects the family or estate of the unit-holder who meets his monthly paymants promptly, against all possibility of loss due to his death. 



\section{and}

(n)

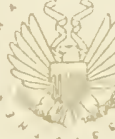

+

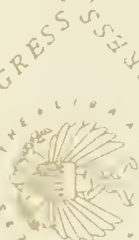

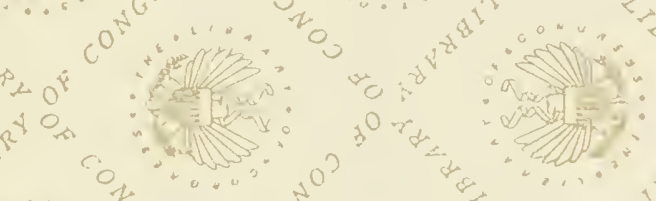

$-8 \cos ^{5}$

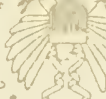

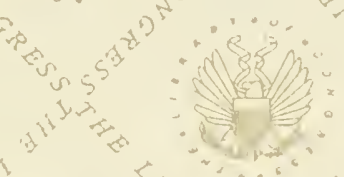

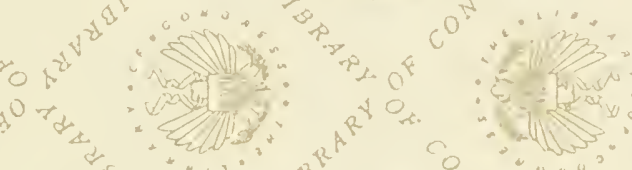

(2)

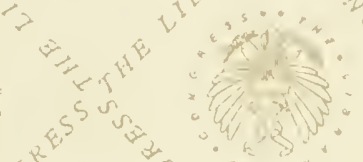

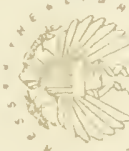

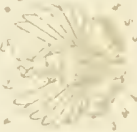

$5^{3}-1$
$2^{2}-1$

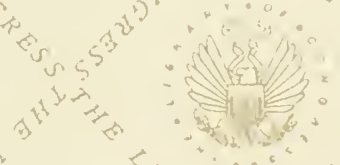

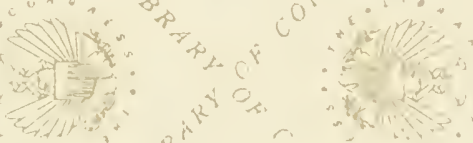

(i)

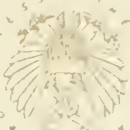

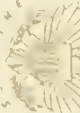

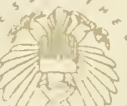

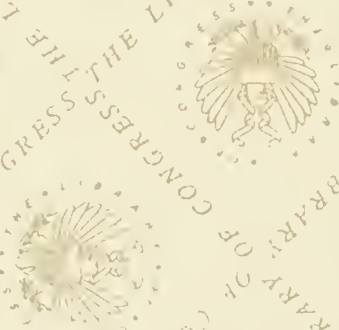

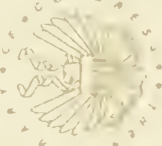
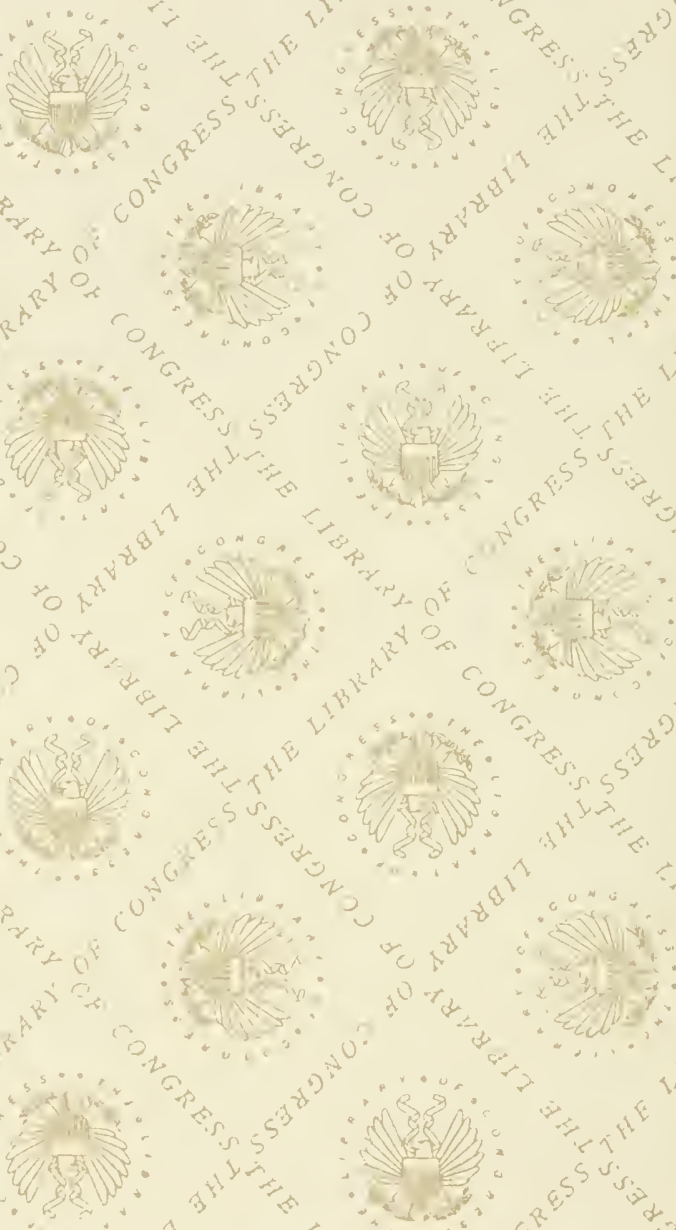

s.
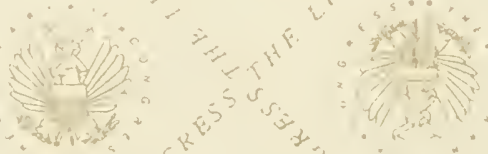

and
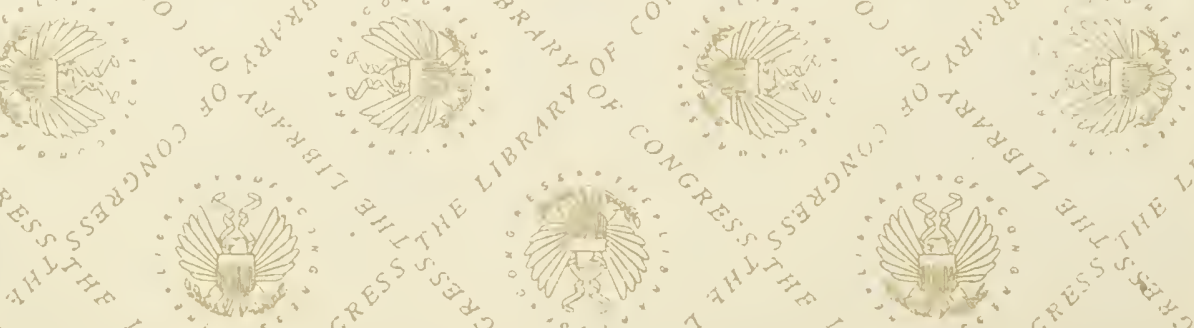

LIBRARY OF CONGRESS

|||||||||||||||||||||||||||||||||||||||||||

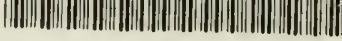

00009188411 